\title{
Influence of sea ice on primary production in the Southern Ocean: A satellite perspective
}

Walker O. Smith Jr.

Virginia Institute of Marine Science, wos@vims.edu

Josefino C. Comiso

NASA Goddard Space Flight Center

Follow this and additional works at: https://scholarworks.wm.edu/vimsarticles

Part of the Marine Biology Commons

\section{Recommended Citation}

Smith, Walker O. Jr. and Comiso, Josefino C., "Influence of sea ice on primary production in the Southern Ocean: A satellite perspective" (2008). VIMS Articles. 270.

https://scholarworks.wm.edu/vimsarticles/270

This Article is brought to you for free and open access by W\&M ScholarWorks. It has been accepted for inclusion in VIMS Articles by an authorized administrator of W\&M ScholarWorks. For more information, please contact scholarworks@wm.edu. 


\title{
Influence of sea ice on primary production in the Southern Ocean: A satellite perspective
}

\author{
Walker O. Smith Jr. ${ }^{1}$ and Josefino C. Comiso ${ }^{2}$ \\ Received 30 March 2007; revised 8 November 2007; accepted 26 February 2008; published 23 May 2008.
}

[1] Sea ice in the Southern Ocean is a major controlling factor on phytoplankton productivity, but the relationship is modified by regional differences in atmospheric and oceanographic conditions. We used the phytoplankton biomass, photosynthetically active radiation (PAR), and cloud cover data from Sea-viewing Wide Field of View Sensor (SeaWiFS), ice concentrations data from Special Sensor Microwave Imager (SSM/I) and Advanced Microwave Scanning Radiometer-EOS (AMSR-E), sea-surface temperature data from advanced very high resolution radiometer (AVHRR), and a vertically integrated model to estimate primary productivity south of $60^{\circ} \mathrm{S}$. We also selected six areas within the Southern Ocean and analyzed the variability of the primary productivity and trends through time. We found substantial interannual variability in productivity from 1997 to 2005 in all regions of the Southern Ocean, and this variability appeared to be driven in large part by ice dynamics. The most productive regions of Antarctic waters were the continental shelves, and no sustained blooms occurred in waters of greater depth $(>1000 \mathrm{~m})$. We suggest that this is due to the slightly greater mixed layer depths found in waters off the continental shelf, and that the interactive effects of iron and irradiance result in the limitation of phytoplankton biomass over large regions of the Southern Ocean. Annual productivity of the Southern Ocean averaged $23.65 \mathrm{~g} \mathrm{C} \mathrm{m}^{-2} \mathrm{a}^{-1}$, but yearly means for the years between 1998 and 2004 ranged from 22.10 to $25.49 \mathrm{~g} \mathrm{C} \mathrm{m}^{-2} \mathrm{~d}^{-1}$, respectively. Annual primary productivity over the entire Southern Ocean appears to have increased significantly since 1998, and much of this increase was confined to the months of January and February. Causes for this trend are presently unclear.

Citation: Smith, W. O., Jr., and J. C. Comiso (2008), Influence of sea ice on primary production in the Southern Ocean: A satellite perspective, J. Geophys. Res., 113, C05S93, doi:10.1029/2007JC004251.

\section{Introduction}

[2] Sea ice is of paramount importance in controlling phytoplankton productivity, growth and biomass in polar regions on all scales. At the small scale, sea ice can release epontic algae into the water, providing to the water column an inoculum of species that either continue their growth in the surface layer or rapidly sink through the water column to depth [Thomas, 2004]. Mesoscale processes, such as ice melt, also influence phytoplankton. For example, the production of meltwater and the generation of a stratified surface layer can give rise to increased phytoplankton growth and accumulation within the marginal ice zone (MIZ) [Smith and Nelson, 1985], and depending on how rapidly the ice edge retreats, can be a major site of autotrophic production for the entire Southern Ocean [Smith and Nelson, 1986]. On the large scale, ice is the major regulator of the availability of irradiance to phytoplankton,

\footnotetext{
${ }^{1}$ Institute of Marine Sciences, College of William and Mary, Gloucester Point, Virginia, USA.

${ }^{2}$ NASA Goddard Space Flight Center, Greenbelt, Maryland, USA.

Copyright 2008 by the American Geophysical Union. 0148-0227/08/2007JC004251
}

and hence controls the large-scale distribution of phytoplankton abundance and production.

[3] However, because the physical forcing varies from region to region, the effects of melting ice in the marginal ice zone are variable. For example, in the Ross Sea ice initially is reduced in its ice cover via polynya formation and ice advection, and continued expansion then is normally determined by ice retreat to the east and west that is driven by in situ melting [Tremblay and Smith, 2007]. A stratified surface layer is generated that can vary in thickness in both space and time on the basis of the amount of meltwater input [Smith et al., 2006]. In the Bellingshausen Sea the zone of enhanced biomass of phytoplankton was associated with a current-generated front, rather than the melting ice [Boyd et al., 1995; Waldron et al., 1995], whereas in the Weddell Sea the MIZ was with the site of enhanced phytoplankton accumulation, although variations along the ice were observed [Nelson et al., 1987]. Ice-edge phytoplankton blooms are not routinely observed in the East Antarctica region [e.g., Strutton et al., 2000]. Phytoplankton biomass over the broad region in the Pacific sector of the Antarctic Convergence Current (ACC) was coupled to ice retreat [Moore et al., 1999] and nutrient removal as modified by iron limitation [Hiscock et al., 2003]. While ice 
retreat undoubtedly introduces low-density water to the surface layer, it does not in all cases increase stratification for long enough to allow for a marked phytoplankton growth stimulation and accumulation.

[4] Smith and Nelson [1985] also suggested that the spatial extent of an ice-edge bloom would be constrained by the wind-induced reduction in stratification away from the ice. This was based on density determinations of sections that extended some $300 \mathrm{~km}$ from the ice edge, and was supported by work of Alexander and Niebauer [1981] in the Bering Sea, who reported phytoplankton blooms in the MIZ that were delineated by the extent of stratification. However, longer sections in the Ross Sea have shown that sufficient stratification occurs within the entire polynya during the ice-free period, although slightly deeper mixed layers routinely occur away from the ice edge [Smith and Asper, 2001; Smith et al., 2006]. Seasonal variations in the depth of the mixed layer are far greater than the differences between the ice-edge and central region, and it appears that the deepening of the mixed layer and the erosion of stratification is primarily driven by ice formation and brine rejection, rather than by increases in winds [Tremblay and Smith, 2007]. Therefore, the spatial extent of any ice-edge bloom likely varies as a function of regional physical forcing.

[5] Estimates of the productivity of the Southern Ocean, either regional or basin-wide, have substantial uncertainty. Early estimates suggested that the overall productivity of the Southern Ocean averaged $16 \mathrm{~g} \mathrm{C} \mathrm{m}^{-2} \mathrm{a}^{-1}[$ Holm-Hansen et al., 1977], which is similar to (or lower than) rates in subtropical oceans. Inclusion of the marginal ice zone productivity increased the estimate by $60 \%$ [Smith and Nelson, 1986], but all of the above estimates had extremely large uncertainties. Arrigo et al. [1998b] used data from the $\mathrm{SSM} / \mathrm{I}$ and CZCS satellite sensors and estimated that the productivity of the Southern Ocean was some four times greater than had previously been estimated, but the accuracy of the model results is compromised by errors in the CZCS chlorophyll estimates, relatively poor spatial/ temporal resolution, and substantial effects of clouds. A similar approach was used by Moore and Abbott [2000], who estimated productivity south of $50^{\circ} \mathrm{S}$ to be from 62 to $82 \mathrm{~g} \mathrm{C} \mathrm{m}^{-2} \mathrm{a}^{-1}$, depending on the assumptions used. However, these were the first attempts to uniformly treat the productivity of the entire Southern Ocean and estimate its productivity using remote sensing, similar to what had been attempted in other oceanic regions [e.g., Behrenfeld and Falkowski, 1997; Campbell et al., 2002; Behrenfeld et al., 2006].

[6] Here we use an approach similar to that of Arrigo et al. [1998b] and Moore and Abbott [2000] to study the productivity of the Southern Ocean, in that we incorporate phytoplankton pigment assessments, surface temperature estimates, modeled irradiance, and observed ice concentrations, and incorporate them into a vertically integrated production model to estimate productivity according to the technique of Behrenfeld et al. [2002]. We also select six regions to assess the decadal changes in productivity at those sites, and also assess the relationship between phytoplankton productivity with ice concentrations (a proxy for stratification) and bathymetry in waters of the Antarctic. The resultant assessment of Southern Ocean productivity is the most exhaustive ever compiled and provides an improvement in the quantitative role of carbon fixation in Antarctic waters.

\section{Materials and Methods}

[7] The key parameters used in this study are ice concentrations, sea surface temperatures, phytoplankton pigment concentrations, photosynthetically active radiation (PAR), and cloud cover, all of which are derived from satellite data. Ice concentrations and associated parameters (e.g., ice extent and area) were derived using data from the Special Sensor Microwave Imager (SSM/I) on the Defense Meteorological Satellite Program (DMSP) and mapped on a polar stereographic grid at a $25 \times 25 \mathrm{~km}$ resolution. Ice concentrations were derived from satellite passive microwave data using the enhanced Bootstrap algorithm used for AMSR-E data and adapted for SSM/I data [e.g., Comiso et al., 2003; Comiso, 2004]. Sea surface temperatures were derived from thermal infrared channels of the NOAA/ Advanced Very High Resolution Radiometer (AVHRR) as described by Comiso [2003]. Pigment concentrations derived from Sea-viewing Wide Field of View Sensor (SeaWiFS) data were provided by the NASA/Goddard Earth Sciences (GES)/Distributed Active Archive Center (DAAC). Surface temperature and pigment concentration data have been gridded in the same manner as the sea ice concentration data but at a $6.25 \times 6.25 \mathrm{~km}$ resolution. Daily, average pigment concentrations were estimated using the standard SeaWiFS algorithm with OC4 (Version 4) calibration [Patt et al., 2003] and used to generate weekly (7-d bins) and monthly data sets from 1997 to 2006. PAR data were extracted as part of the SeaWiFS data and treated similarly. It is important to note that because of cloud and ice masking the weekly and monthly averages do not reflect true averages, but are averages of daylight data (for each data element) available during clear-sky, icefree conditions only.

[8] Temperature, PAR and chlorophyll concentrations were used with a vertically generalized production model [Behrenfeld and Falkowski, 1997] in which primary productivity $\left(\mathrm{PP}_{\mathrm{eu}}\right.$, in units of $\left.\mathrm{mg} \mathrm{C} \mathrm{m} \mathrm{m}^{-2} \mathrm{~d}^{-1}\right)$ was calculated by the following equation:

$$
P P_{e u}=0.66125 \times P_{o p t}^{B} \frac{E_{o}}{E_{o}+4.1} C_{S a t} \times Z_{e u} \times D_{I r r},
$$

where $P_{o p t}^{B}$ is the optimal rate of photosynthesis within the water column (mg C (mg chl) $\left.)^{-1} \mathrm{~h}^{-1}\right)$ and is regulated by temperature, $E_{o}$ is the surface daily PAR (mol photons $\mathrm{m}^{-2} \mathrm{~d}^{-1}$ ), $\mathrm{C}_{\text {sat }}$ is the surface chlorophyll

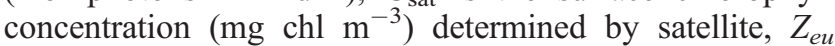
is the depth of the euphotic zone in meters, and $D_{I r r}$ is the photoperiod (h). $P_{o p t}^{B}$ was estimated from sea surface temperatures by the polynomial equation of Behrenfeld and Falkowski [1997], and all values at temperatures less that $-1.0^{\circ} \mathrm{C}$ were set to $1.13 \mathrm{mg} \mathrm{C}(\mathrm{mg} \mathrm{chl})^{-1} \mathrm{~h}^{-1} . Z_{e u}$ was calculated from the integrated chlorophyll concentration, which in turn was calculated from the surface chlorophyll concentration. Productivity was calculated on a daily basis, and binned in a manner similar to that of chlorophyll. The gridding technique (the so-called "drop in a bucket" 


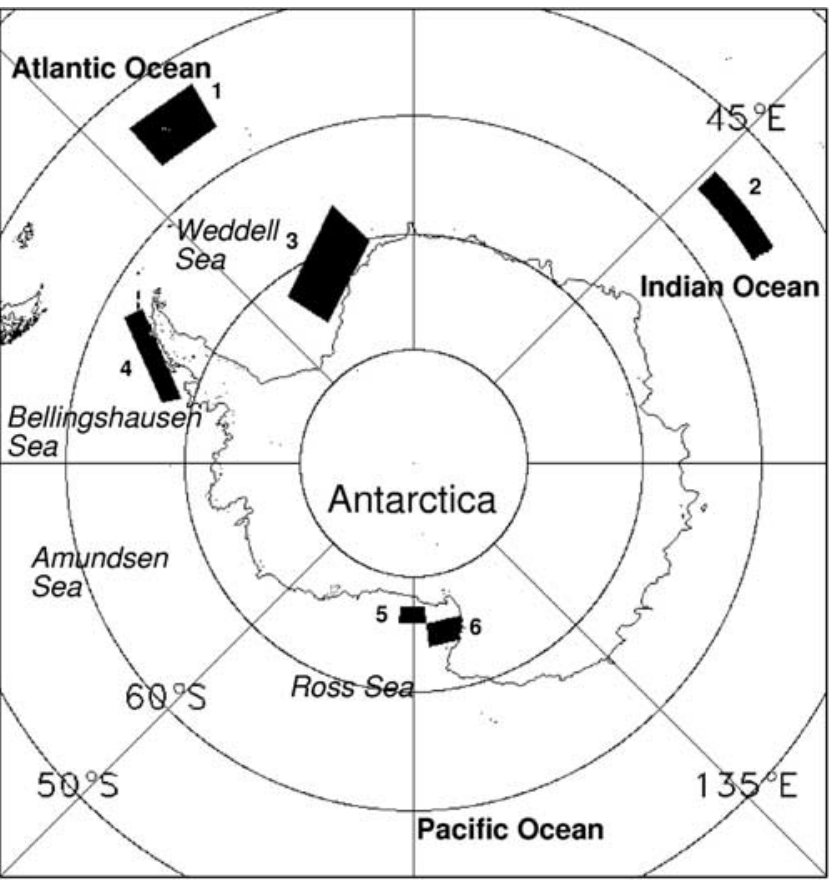

Figure 1. Location of regions within the Southern Ocean selected for detailed analysis: 1, ACC region; 2, Indian Ocean; 3, Weddell Sea; 4, West Antarctic Peninsula (WAP); 5, Ross Sea I; 6, Ross Sea II.

procedure) and the presence of clouds caused a large fraction of data elements (pixels) in the daily maps to have missing data. In the case where a single empty or voided pixel is surrounded by pixels with data, a simple interpolation technique is utilized to fill the empty pixel. For slightly larger data gaps of a few pixels, a combination of spatial and temporal interpolation was utilized. Such interpolation filled only a very small fraction of missing data in the daily map, and for time series studies weekly averages were produced as the basic product. Yearly means were simple summations of daily rates.

[9] Modeled irradiance was computed after the clear-sky model of Gregg and Carder [1990]; in addition, surface PAR was obtained from the SeaWiFS satellite [Arrigo and van Dijken, 2004]. Photoperiod can be relatively easily modeled, as it is solely a function of latitude. Modeled PAR can by definition be extended to any resolution, whereas measured PAR is biased by cloud cover and is limited to the resolution of the sensor. Both modeled and measured estimates of PAR were tested in the productivity model, and surprisingly it was found that there was little difference between the two. As a result, we used the modeled PAR for our full analysis, especially since the surface PAR data that are available were not quality controlled (in terms of ice and ocean mask) in the polar regions.

[10] We recognize that regional algorithms have been developed for certain parts of the Southern Ocean (e.g., Ross Sea [Arrigo et al., 1998b; Dierssen and Smith, 2000; Garcia et al., 2005]), and that these formulations may provide a more accurate estimate of phytoplankton biomass in each area where the measurements were made. We chose to use the output from the standard global algorithm to simplify the comparison of regions and of various years, to facilitate a comparison among all regions, and to avoid problems of defining boundaries of optically different regions. While this approach may introduce error into absolute estimates of productivity within a region, it provides a uniform basis to compute productivity throughout the Southern Ocean, as regional algorithms (some of which need more rigorous validation) are not available for all areas. We also chose specific regions for a more in-depth analysis (Figure 1). These regions (Ross Sea I (RS I): the southern Ross Sea; Ross Sea II (RS II), the central Ross Sea; the West Antarctic Peninsula (WAP), the South Georgia region in the Antarctic Circumpolar Current (ACC); the Weddell Sea (WS); and the Indian Ocean (IO)), were selected on the basis of their large seasonal ice variations and enhanced productivity values measured previously using discrete methods. The Indian Ocean study region was identified as a region with consistently low pigment concentrations and included to assess how the variability of an area that is a site of persistently deep, wind-induced mixed layers and low productivity compares with the biomass and productivity of the other selected regions. Trends were determined by simple Model I regression analyses.

\section{Results}

\subsection{Irradiance}

[11] Irradiance has two components: photoperiod and absolute irradiance impinging on the sea surface. Within the Southern Ocean, photoperiod varies from 0 to $24 \mathrm{~h}$ within one year, and from 16.3 to $24 \mathrm{~h}$ at the seasonal maximum (21 December). PAR ranged from 0 to $70 \mathrm{~mol}$ photons $\mathrm{m}^{-2} \mathrm{~d}^{-1}$ within the year, and maxima ranged from 63 to $68 \mathrm{~mol}$ photons $\mathrm{m}^{-2} \mathrm{~d}^{-1}$ among the selected study regions. PAR was the same as the scalar irradiance calculated by others [e.g., Mitchell and Holm-Hansen, 1991].

\subsection{Ice Concentrations}

[12] To show spatial variations in the distribution of ice concentration during late winter through austral spring and summer (when blooms are most likely to occur) and autumn, multiyear, monthly averages of ice concentrations were calculated for the years that SeaWiFS provided data (Figure 2). In October the ice cover is still fully consolidated throughout the Antarctic region, but reduced concentrations are found in many coastal areas. Coastal polynyas along most of these regions are more apparent in December, especially in the Ross Sea. In February, much of the coastline becomes completely ice-free, with persistent ice cover being prevalent in the Western Weddell Sea and the Amundsen/ Bellingshausen Seas. In April, when rapid ice growth in deeper water occurs, reduced concentrations along the coastlines continue. The average concentration of the entire Antarctic sea ice cover in December (Figure 3) fluctuates from about 55-65\% from 1997 through 2006, with a majority of the fluctuations occurring during the last five years. The trend in ice concentration also shows a decline of about $2 \%$ per decade. In the selected study regions the average ice concentration varies seasonally (Figures $4 \mathrm{a}$ and $4 \mathrm{~b}$ ), except in the ACC and Indian Ocean, where little ice occurs throughout the year. In the Weddell 

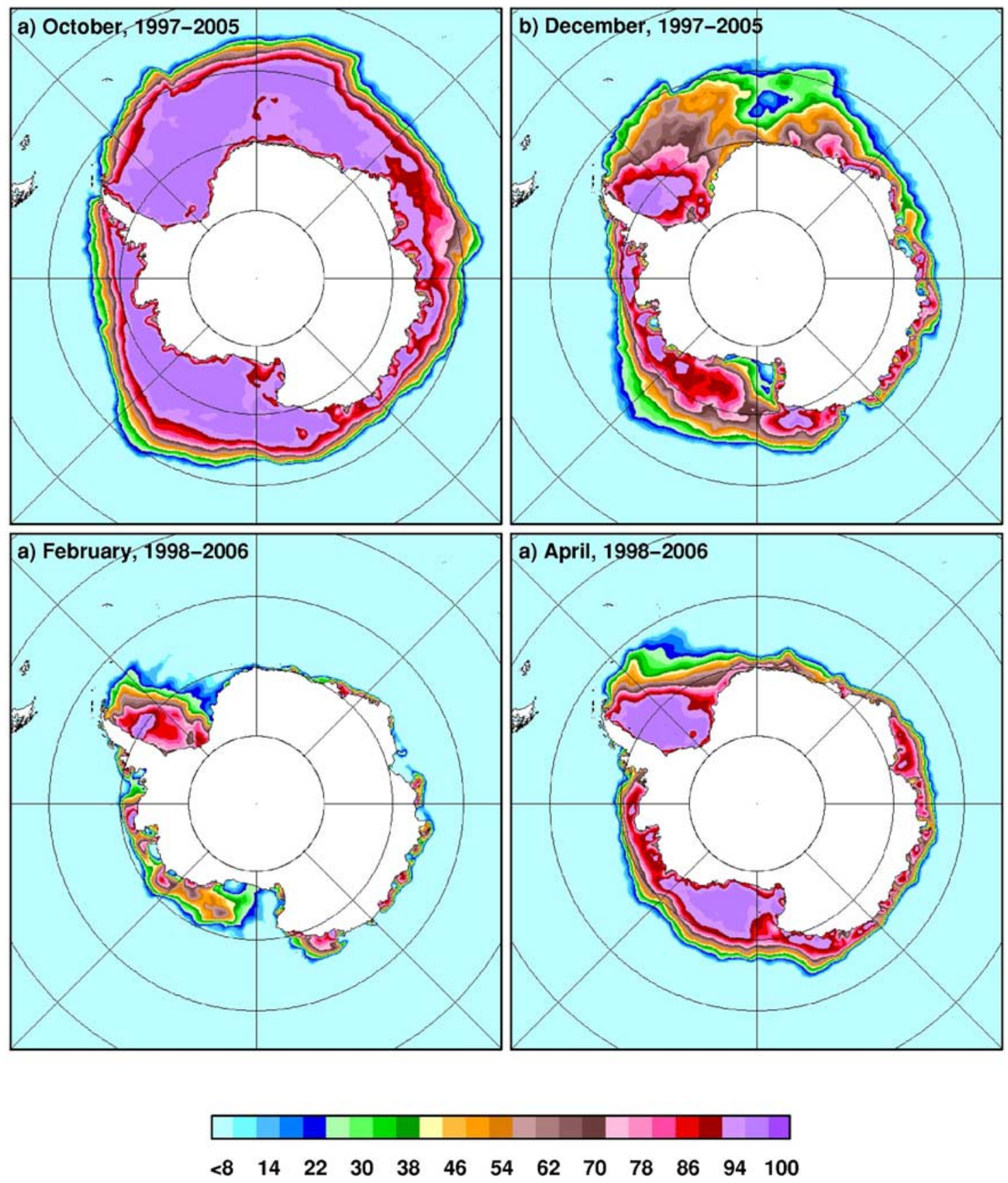

Figure 2. Mean ice concentrations for the Southern Ocean from 1997-2006 during (a) October, (b) December, (c) February, and (d) April.

Sea and Ross Sea study areas, the ice cover is near $100 \%$ in winter but exhibits large variability in the summer, while in the WAP the summer ice cover is almost zero, but exhibits large variability in the winter. The percentage of open water $(1$ - ice cover percentage) varies in a similar manner. Thus, in the Weddell Sea study area the average open-water percentage during summer ranges from 30 to $100 \%$, while in the Ross Sea study area II open water averages from 28 to $72 \%$. The Ross Sea I study area averages open water concentrations of $10-20 \%$ in winter and $50-100 \%$ in summer, with $100 \%$ values occurring in 1997, 1999, 2000, 2002, 2005 and 2006.

\subsection{Surface Temperature}

[13] While sea surface temperatures (SST) have been used to study oceanographic processes in polar regions [e.g., Kwok and Comiso, 2002], they have not been used previously to evaluate spatial variability of plankton concentrations in the region. In the Southern Hemisphere south of $60^{\circ} \mathrm{S}$, the spatial distribution of SST is heavily influenced by the melting of sea ice during the spring and summer. The data are thus useful to assess the degree to which temperatures are correlated with phytoplankton growth and accumulation, but also the fate of the low-density meltwater after sea ice melt. Monthly averages of SST in December from 


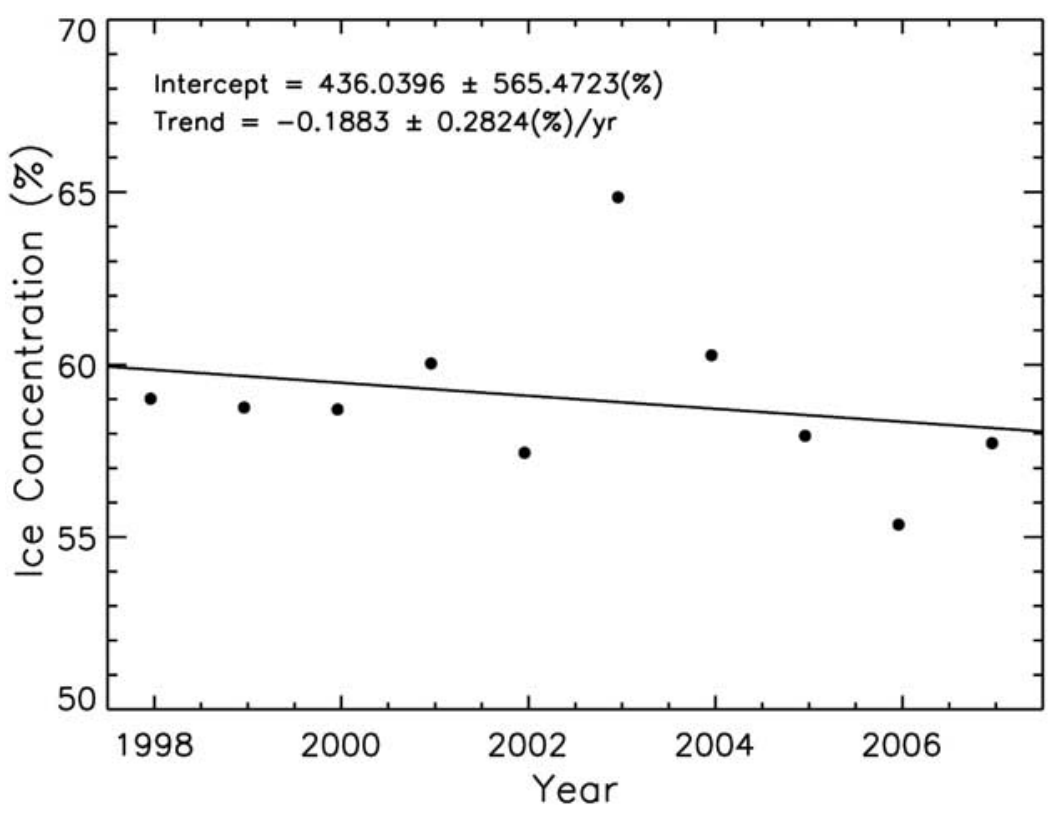

Figure 3. Mean ice concentrations in December for the years 1997-2006.

1997 to 2005 (Figure 5) provide the means to evaluate spatial distributions of SST and relationships with sea ice locations (in white). The surfaces with near-freezing temperatures in the maps are likely the surfaces influenced by sea ice, and it is apparent that the interannual variability of the extent and location of these surfaces is large. In general the temperatures reflect the distribution of ice as well as the north-south gradient in the surface heat budget. However, one area deviates substantially among years: the ice edge at the Greenwich meridian. In some years (e.g., 1998, 2000, 2004) warm water clearly is advected under the ice and initiates melting, opening large areas to the atmosphere, and surface water temperatures are near $0^{\circ}$. The exact location of this intrusion, as well as the strength of its surface signal, also varies substantially among years as well.

[14] The seasonality and interannual variability of SST in the various study regions (Figures 6a and 6b) show that the regional as well as interannual variability is large. The warmest waters in all of the study regions are in the ACC, although there were times (e.g., 1998 and 2001) when the Indian Ocean study area was warmer during summer. There are no data in Weddell and Ross Sea study areas during parts of the year when they are covered by sea ice, but the SST in these regions is undoubtedly close to the freezing point of seawater. December sea surface temperatures ranged from the freezing point $\left(\sim-1.86^{\circ} \mathrm{C}\right.$, or $\left.271.3^{\circ} \mathrm{K}\right)$ in the Ross Sea to more than $10^{\circ} \mathrm{C}\left(283.2^{\circ} \mathrm{K}\right)$ in the $\mathrm{ACC}$ region (Figure 6a). Seasonal ranges were greatest in the ACC $\left(\sim 5.6^{\circ} \mathrm{C}\right)$, followed by the Indian Ocean and WAP study areas, while those in the ice covered regions show more moderate seasonality (Figures 6a and 6b). Specifically, Ross Sea I and II and Weddell Sea areas all had a range of about $2^{\circ} \mathrm{C}$, while that of the WAP was about $3{ }^{\circ} \mathrm{C}$.

\subsection{Pigment Distribution}

[15] The distribution of chlorophyll $a$ in the Southern Ocean was previously studied [Comiso et al., 1993; Sullivan et al., 1993; Moore and Abbott, 2000]; using Nimbus-7/
CZCS data, but spatial and temporal coverage was restricted and seasonally biased. This improved substantially with the collection of SeaWiFS data [Moore and Abbott, 2000]. The compendium presented in Figure 7 is currently the most comprehensive representation of yearly and multiyear averages of plankton concentration in the Southern Ocean. The data provide the means to identify regions with persistently high chlorophyll a concentrations; similarly, they also indicate where the persistently low concentrations occur. The composite also illustrates how the pigment concentrations and distributions vary among years. The images show that maxima are largely confined to continental shelf regions, and in particular to those polynyas where ice concentrations become reduced during the growing season (Figure 7). Seasonal variations were large at any single location, and could range from zero to greater than $20 \mathrm{mg} \mathrm{m}^{-3}$ in regions like the Ross or Weddell Seas. Open ocean regions showed much smaller maxima, and only occasionally exceeded $1 \mathrm{mg} \mathrm{m}^{-3}$. The Pacific sector was an exception to this, and seemed to have slightly greater chlorophyll levels than other areas of the Southern Ocean at a similar latitude and depth.

[16] Pigment concentrations in the selected study areas showed substantial variations among themselves, as well as large interannual variations (Figures $8 \mathrm{a}$ and $8 \mathrm{~b}$ ). The greatest concentration of chlorophyll was found in the southern Ross Sea (RS I), followed by the central Ross Sea (RS II), the ACC, the Weddell Sea, the West Antarctic Peninsula and the Indian Ocean. Mean annual concentrations (calculated from all ice-free retrievals) and their standard deviations were $0.31 \pm 0.02,2.19 \pm 0.98$, $1.22 \pm 0.29,0.39 \pm 0.17,0.54 \pm 0.17,0.34 \pm 0.06$, and $0.14 \pm 0.01 \mathrm{mg} \operatorname{chl} a \mathrm{~m}^{-3}$ in the entire Southern Ocean, RS I, RS II, ACC, WS, WAP and IO, respectively.

\subsection{Primary Productivity}

[17] Primary productivity of entire Southern Ocean south of $60^{\circ} \mathrm{S}$ was strongly correlated with pigment concentrations (Figure 9). Annual productivity of the entire Southern 


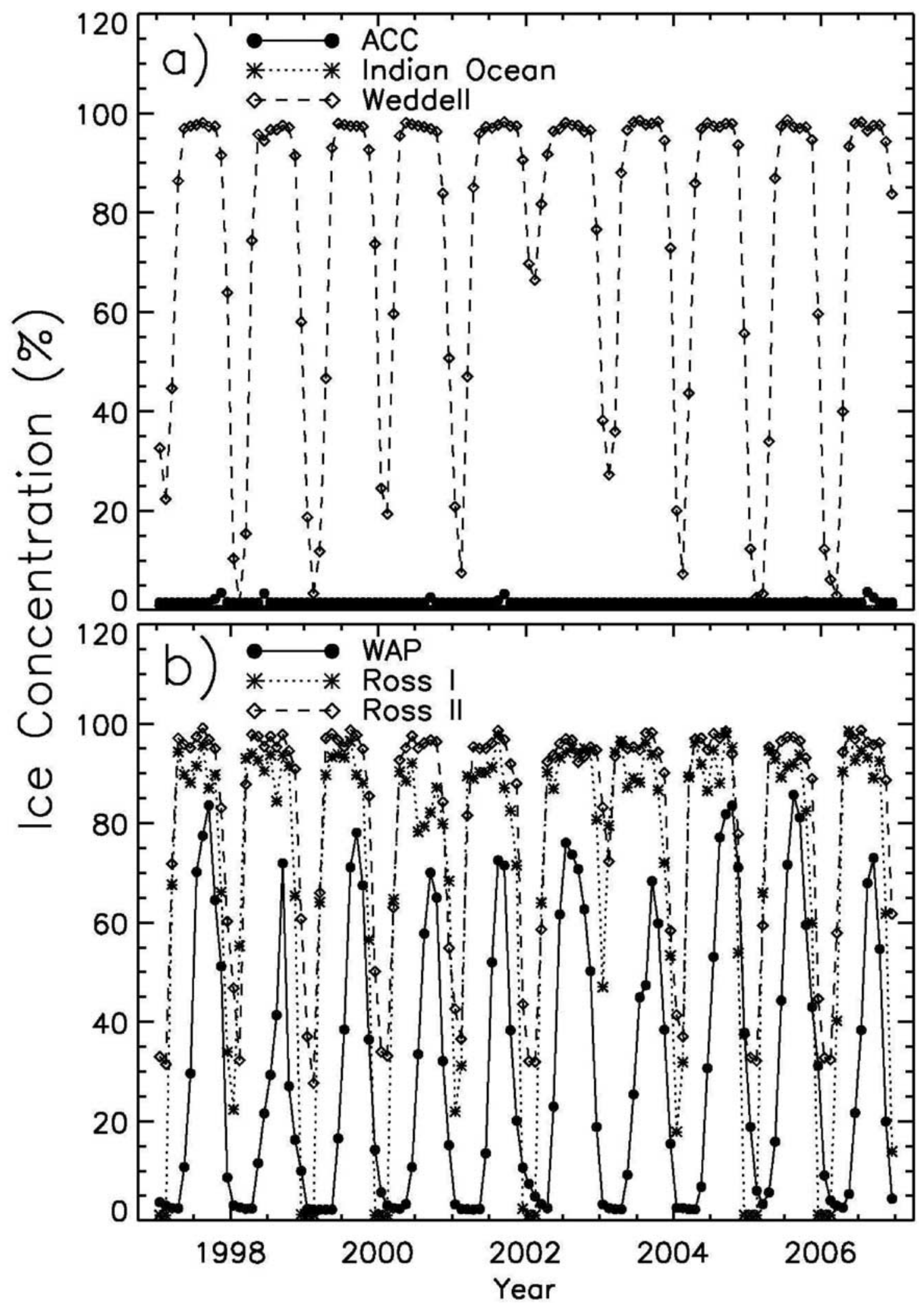

Figure 4. Variations of percentage of ice cover through time in (a) the Weddell Sea, Indian Ocean, and ACC areas and (b) the two Ross Sea regions and the West Antarctic Peninsula. 

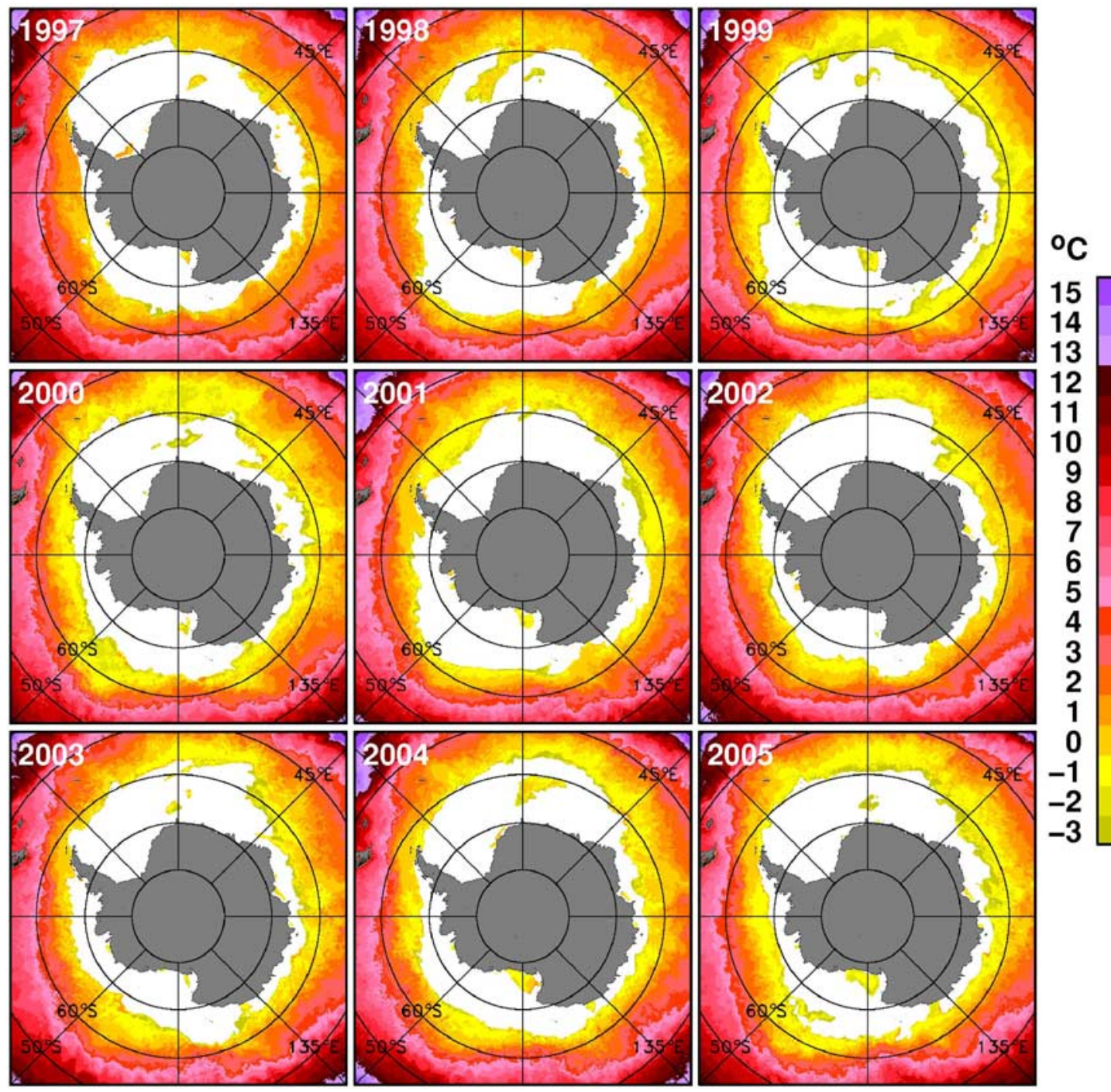

12
11
10
9
8
7
6
5
4
3
2
1
0
-1
-2
-3

Figure 5. Mean December sea surface temperatures for the Southern Ocean for the years 1997-2005.

Ocean (south of $60^{\circ} \mathrm{S}$ ) equaled $23.65 \pm 1.28 \mathrm{~g} \mathrm{C} \mathrm{m}^{-2} \mathrm{a}^{-1}$ (Table 1). Means and standard deviations for the six selected regions were $2.74 \pm 0.98$ for RS I, $2.26 \pm 0.59$ for RS II, $1.56 \pm 0.50$ for the WAP, $0.75 \pm 0.28$ for the WS, $2.83 \pm$ 0.40 for the $\mathrm{ACC}$, and $1.71 \pm 0.16 \mathrm{~g} \mathrm{C} \mathrm{m}^{-2} \mathrm{~d}^{-1}$, respectively. Monthly (from November through March) mean productivity of the entire Southern Ocean showed dramatic temporal and spatial variations (Figure 9), with the largest variations being associated with the extreme maxima of coastal regions. The influence of the marginal ice zone is relatively minor in this analysis, but the maximum chlorophyll concentration observed generally occurs about six weeks after the disappearance of ice. There also is a notable lack of deep-water $(>1000 \mathrm{~m})$ blooms throughout the Southern Ocean, suggesting that productivity in these areas is limited by irradiance, trace metal availability, other factors or by their interactive effects.

[18] The temporal trends of primary productivity among the selected regions show marked differences (Figure 10). One feature that is obvious is that polynyas (e.g., the Ross and Weddell Seas) bloom much earlier than other regions of similar latitude, and even substantially before areas of similar depth that are much farther north. For example, in RS I $\left(\sim 77^{\circ} \mathrm{S}\right)$ chlorophyll $a$ concentrations reach $3 \mathrm{mg} \mathrm{m}^{-3}$ in November, while similar concentrations are rarely observed in the WAP $\left(\sim 64^{\circ} \mathrm{S}\right)$ until mid-December. This suggests that for the spring phytoplankton assemblages of the Ross and Weddell Seas the absolute requirement for irradiance for net photosynthesis is quite low, or that stratification in the WAP is far weaker than in the polynyas. However, available data do not support the latter hypothesis [e.g., Mitchell and Holm-Hansen, 1991] (Palmer LTER data, http://pal.lternet.edu/data/). Both polynyas also receive substantial amount of ice algae released into the water column, providing an inoculum for the water column, and this input is likely greater than in the WAP. However, it remains uncertain what factors might cause the early bloom formation, but its appearance has a striking impact on regional productivity.

[19] Productivity for the entire Southern Ocean shows a significant increase over the period of this analysis (Figure 9). Monthly trends were also computed, and 


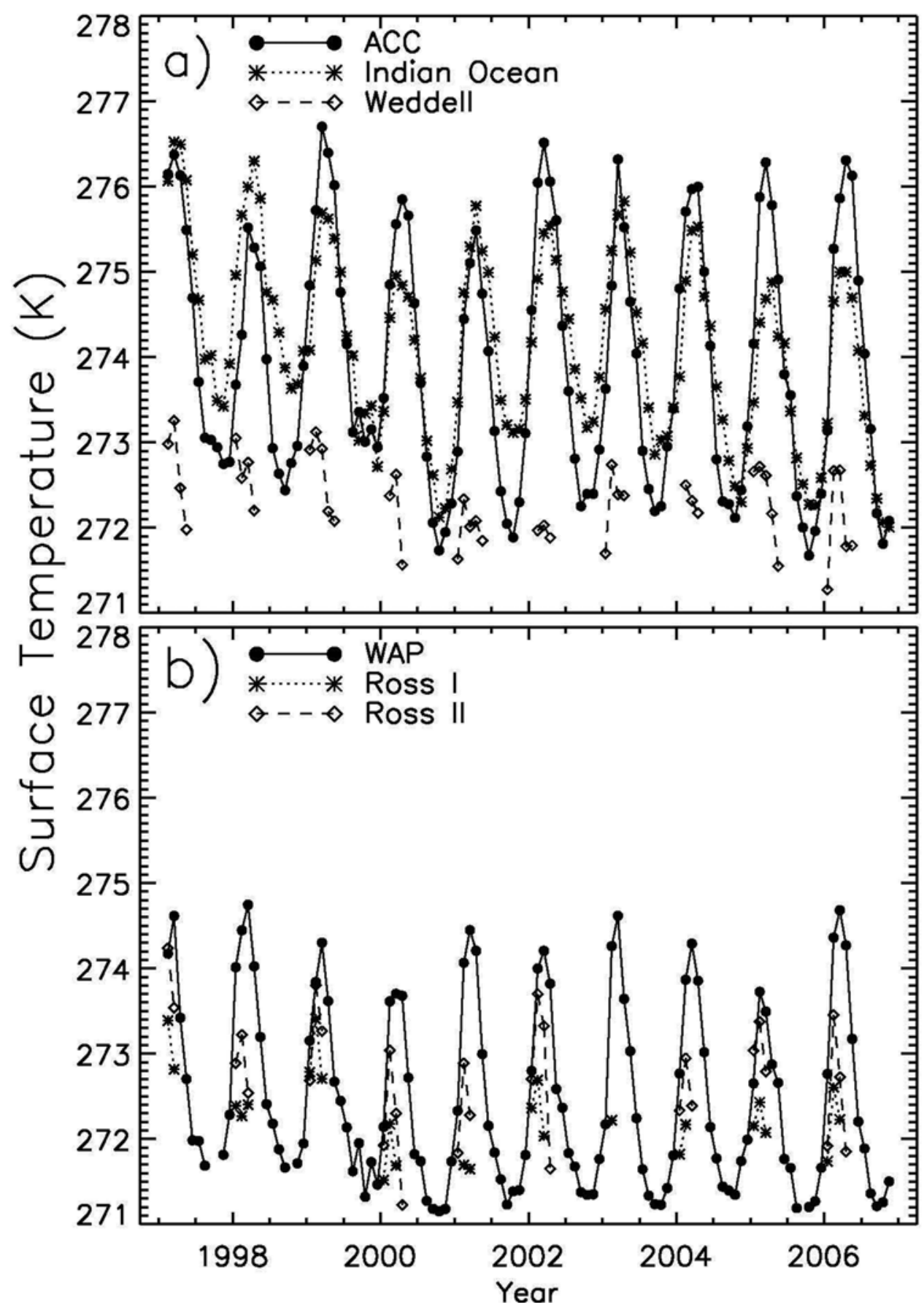

Figure 6. Variations of sea surface temperature through time in (a) the Weddell Sea, Indian Ocean, and ACC areas and (b) the two Ross Sea regions and the West Antarctic Peninsula.

significant increases were noted only for January and February (Figure 9). These two months are also the months of minimum ice concentrations. We believe that this suggests that the summer increases are not directly coupled to ice retreat, but are forced either by changing solar irradiance (and cloud cover) available during these months, or by changing oceanographic conditions that bring iron into the euphotic zone or change stratification. Discriminating among these possibilities is beyond the scope of this analysis. Regardless, the highly significant increase in the productivity of the entire Southern Ocean over the past decade implies that long-term changes in Antarctic food webs and biogeochemical cycles are presently occurring.

\section{Discussion}

[20] During the past three decades large amounts of satellite data from polar regions have been collected, and this in turn has allowed concurrent observation and analysis of large-scale, long-term patterns and trends in a variety of physical and biological features. For example, the spatial 


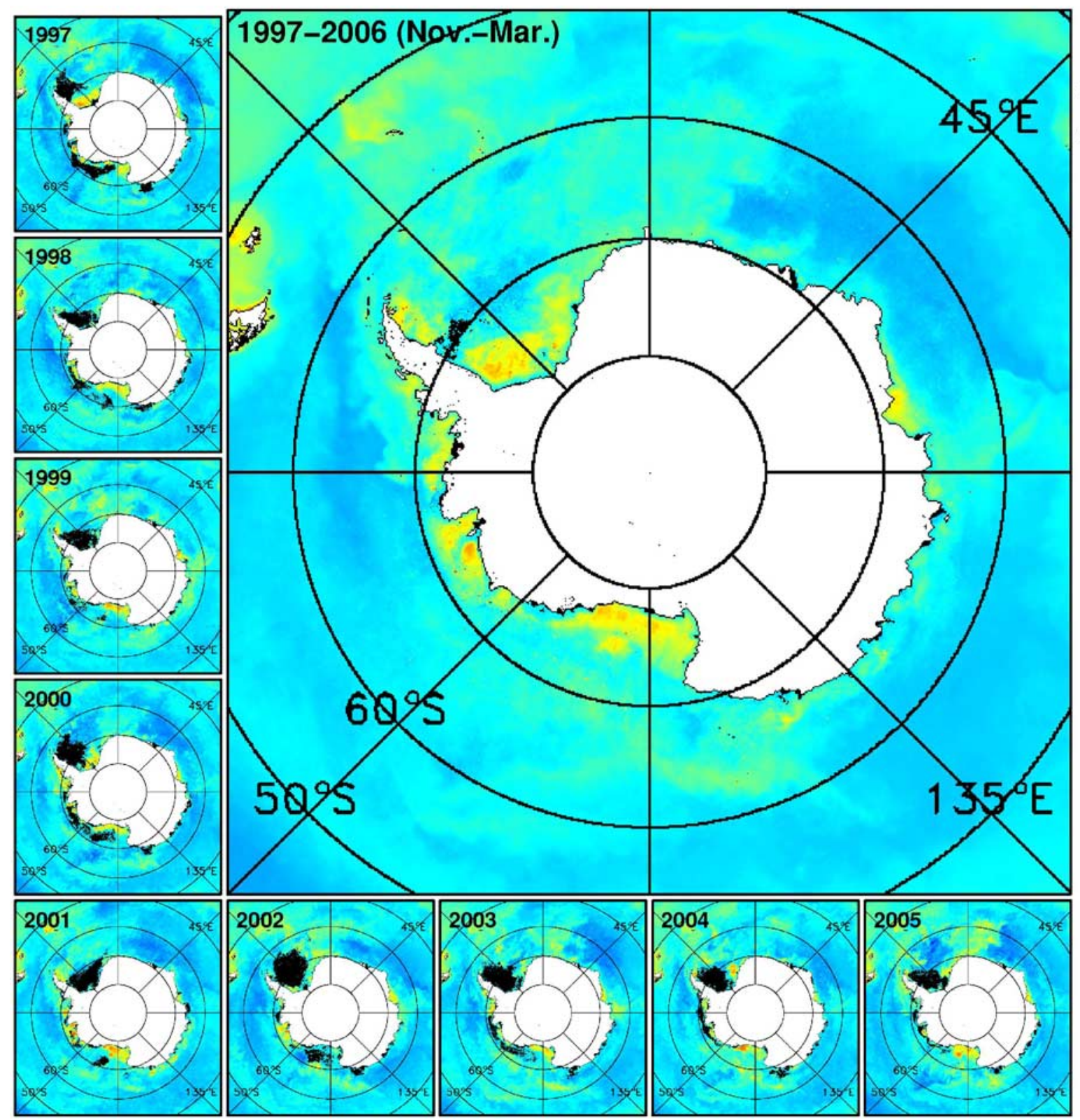

$\mathrm{mg} / \mathrm{m}^{3}$

30.

20.

10.

5.

3.

2.

1.

.5

.3

.2

.1

.05

.03

.02

.01

Figure 7. Mean austral growing season (November-March) chlorophyll concentration throughout the entire Southern Ocean and that of each year from 1998 to 2006. Only ice-free pixels are included in generating the mean. Black represents no data.

and temporal trends in ice concentrations [Zwally et al., 2002; Comiso, 2003], teleconnections to tropical regimes via the Annular Mode [Hall and Visbeck, 2002; Kwok and Comiso, 2002], spatial variations in the location of the Polar Front [Moore and Abbott, 2002], and the persistence and movement of a single patch of phytoplankton [Boyd et al., 2000] were all based on satellite observations. This study represents the first attempt to combine satellite data on ice concentrations, temperature, and SeaWiFS pigment levels for the entire Southern Ocean to estimate, using a vertically integrated model, the primary production of the area south of $60^{\circ} \mathrm{S}$. Our estimate of annual primary productivity is $23.65 \mathrm{~g} \mathrm{C} \mathrm{m}^{-2} \mathrm{a}^{-1}$ (Table 1). This is within the range of previous estimates made using different techniques, data and approaches (Table 2), but given the increased spatial and temporal coverage of our analysis, likely represents the most accurate assessment to date.

[21] The estimates provide a good baseline for productivity studies in the Southern Oceans. However, the estimates are not as accurate as we would like them to be because of a number of reasons. For example, no productivity under the ice is included. While productivity is indeed low under $100 \%$ ice owing to irradiance limitation, it is not zero [Lazzara et al., 2007]. Furthermore, while ice may be present within one pixel, an ice concentration of $50 \%$, for example, does not result in zero productivity, but rather allows a substantial amount of irradiance into the water column to drive production 


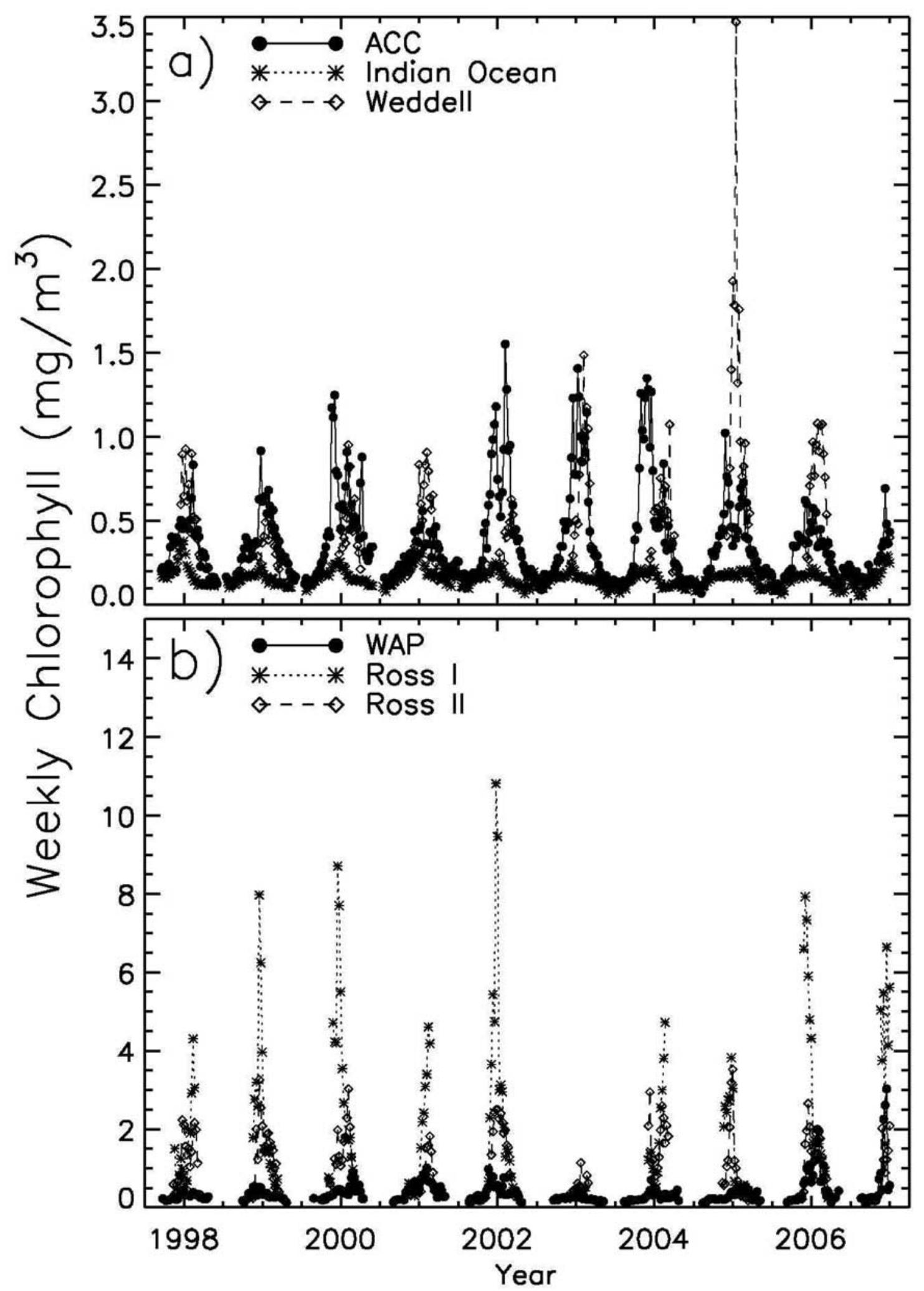

Figure 8. Chlorophyll concentrations from 1997-2006 in (a) the ACC, Indian Ocean, and Weddell Sea areas and (b) the West Antarctic Peninsula and the two Ross Sea regions.

[Smith, 1995]. Our present model and data set are unable to account for this production, and hence produces an underestimate in ice-covered waters. In addition, no attempt to include epontic production is made [Arrigo et al., 1997], which has been estimated to range from 9 to $25 \%$ of productivity in ice-covered waters.

[22] The standard NASA global algorithm used in our procedures may not provide the best estimate of chlorophyll 

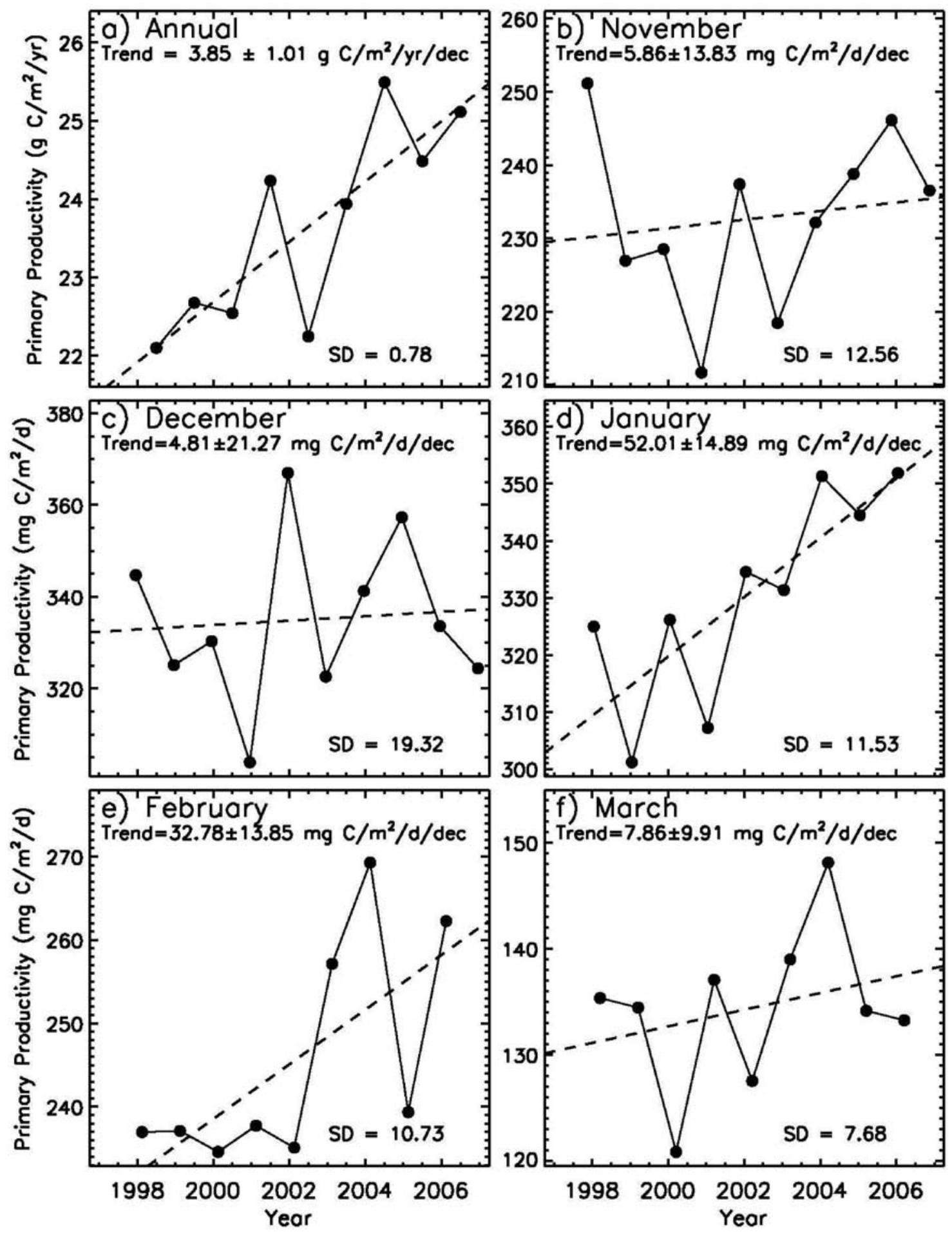

Figure 9. (a) Annual and (b-f) mean monthly (November-March) primary productivity over the entire Southern Ocean from 1997-2006. Annual values computed from computed daily productivity and summed over the ice-free periods. SD is standard deviation of the slope.

$a$ concentrations in some regions, leading to biases in the estimate of productivity in these locations. Using CZCS data, Moore and Abbott [2000] found that changes in the algorithm used can result in a twofold difference in chlorophyll estimates, which in turn give rise to a large difference in productivity estimates. Regional models are unavailable for the entire Southern Ocean; furthermore, there is a substantial variation among regions, making the derivation of a generic Southern Ocean algorithm problematic [e.g., Arrigo et al., 1998b; Dierssen and Smith, 2000; Peloquin and Smith, 2007]. Hence we used the standard algorithm, despite the fact that it may not accurately represent some of 
Table 1. Annual Means ( \pm Standard Deviations), Minima, and Maxima of Primary Production in the Entire Southern Ocean and the Selected Subregions ${ }^{\mathrm{a}}$

\begin{tabular}{|c|c|c|c|}
\hline Region & Mean Production, $\mathrm{g} \mathrm{C} \mathrm{m}^{-2} \mathrm{a}^{-1}$ & Minimum Production, $\mathrm{g} \mathrm{C} \mathrm{m}^{-2} \mathrm{a}^{-1}$ & Maximum Production, $\mathrm{g} \mathrm{C} \mathrm{m}^{-2} \mathrm{a}^{-1}$ \\
\hline Southern Ocean & $23.65 \pm 1.28$ & $22.10(1998)$ & $25.49(2004)$ \\
\hline Ross Sea I & $65.11 \pm 24.98$ & $15.97(2003)$ & $88.29(2001)$ \\
\hline Ross Sea II & $54.14 \pm 14.54$ & $25.63(2003)$ & $80.10(2004)$ \\
\hline West Antarctic Peninsula & $37.30 \pm 11.83$ & $26.89(2004)$ & $61.63(2006)$ \\
\hline Weddell Sea & $18.17 \pm 6.86$ & $6.68(2002)$ & $30.87(2005)$ \\
\hline Antarctic Circumpolar Current & $67.98 \pm 9.61$ & $58.28(2006)$ & $88.06(2003)$ \\
\hline Indian Ocean & $41.12 \pm 3.75$ & $35.79(2005)$ & $45.39(2001)$ \\
\hline
\end{tabular}

${ }^{a}$ Means are from the years 1997-2005. Values in parentheses under minimum and maximum production represent the year of occurrence.

the various subregions within the Southern Ocean. But even assuming that there is a bias in the data generated by using the standard algorithm, the temporal variability and the correlation analysis presented in this paper would still be relevant and the conclusions unchanged.

[23] To assess the accuracy of the model estimates of primary productivity, we correlated in situ observations with the SeaWiFS observations of pigments and modeled estimates of primary productivity (Figures 11a and 11b). The correlation between pigment estimates was relatively very $\operatorname{good}(\mathrm{r}=0.57)$, with a slope of 0.52 and intercept of 0.07 (Figure 11a). This suggests that for these data the satellite retrievals were generally similar to those determined by conventional, ship-based sampling techniques. The discrepancies may not be all associated with problems in the retrieval of SeaWiFS data. Others have found that fluorometric chlorophyll determinations overestimate the absolute levels of chlorophyll due to the production of a fluorescent chlorophyll a precursor [e.g., Marrari et al., 2006; Lance et al., 2007]. Other studies have not provided a mechanistic reason for a variation from in situ values, but reported deviations from a 1:1 correspondence. For example, Holm-Hansen et al. [2004], Korb et al. [2004] and Garcia et al. [2005] found that SeaWiFS overestimated chlorophyll at low concentrations and underestimated it at high concentrations. Gregg and Casey [2004] found a significant underestimate at chlorophyll concentrations greater than $0.15 \mathrm{mg} \mathrm{m}^{-3}$. We also had a positive intercept, suggesting that at low chlorophyll levels the SeaWiFS provides an overestimate. K. R. Arrigo and G. L. van Dijken (Primary production in the Southern Ocean, 1997-2006, submitted to Journal of Geophysical Research, 2008) compiled a more basin-wide data set, but also completed a more regional analysis as well. In the low-biomass offshore waters, the SeaWiFS data underestimated chlorophyll by $\sim 29 \%$. They concluded that if care is taken in interpreting the in situ data (filtering data for nonchlorophyll fluorescent compounds) that the SeaWiFS pigment estimate performs adequately in estimating chlorophyll. Our analysis corroborates the general trends found previously; that is, SeaWiFS provides reasonably accurate estimates of the spatial distribution of chlorophyll in the surface layer of the waters of the Southern Ocean, but there is regional variability to this estimate that cannot at present be adequately explained [Gregg and Casey, 2004].

[24] The comparison of simulated in situ primary production measurements with those estimates made using the vertically integrated model, however, showed marked dis- crepancies (Figure 11b). The correlation between the two was good, but the slope $(r=0.60)$ suggested that SeaWiFS was underestimating productivity by a factor of three $(\mathrm{y}=$ $0.29 x+258.1)$. This could result from a number of factors. Because pigment concentrations account for a substantial amount of the variability in modeled estimates $(\sim 62 \%$ in the West Antarctic Peninsula [Dierssen and Smith, 2000]), the underestimate in low-chlorophyll waters that often is observed will result in an underestimate in productivity of most waters of the Southern Ocean, particularly those that contribute substantially to the basin-wide productivity estimates. The determination of $P_{o p t}^{B}$ could also be improved, as numerous studies [e.g., van Hilst and Smith, 2002; Robinson et al., 2003; Bouman et al., 2005] have shown maximum rates of photosynthesis at low temperatures can be greater than the polynomial-derived value. While a detailed analysis of the potential errors is beyond the scope of this paper, the magnitude of the error suggested by the correlation for the combined data set implies that productivity, as measured by the ${ }^{14} \mathrm{C}$ method, is about 3.4 times greater than that derived from the model. However, we do not believe that the temporal trends observed (Figure 12) will be substantially altered by any underestimates in the model.

[25] One feature of the large-scale distribution of pigments and productivity is that a large fraction of highproductivity regions are confined to the continental shelf regions. This means that the ocean depth may have a strong influence on the productivity observed. To quantitatively assess this relationship, we analyzed the dependence of December pigment concentrations in three separate years (1998, 2003 and 2004) with depth; we found little relationship between the two, and the data exhibited a tremendous amount of scatter (Figure 12). A distinct maximum occurred on the continental shelf (between 400 and $600 \mathrm{~m}$ ) in all years, but somewhat surprisingly, at depths less than $250 \mathrm{~m}$ only modest levels of pigments were observed. The main reason is likely the effects of strong winds from the continent that advect the pigments offshore; it also might result from the fact that the coast often retains significant ice cover during December (Figure 2), and even in areas where the ice had disappeared, the water had been exposed to elevated irradiances for a relatively short period, therefore restricting phytoplankton growth and accumulation. Energetic coastal jets also are commonly found within $\sim 8 \mathrm{~km}$ of the coast, and would enhance vertical turbulence in shallow waters [e.g., Moffat et al., 2008]. While a general negative correlation between ice and chlorophyll has been observed previously [Comiso et al., 1993] other factors may result in reduced pigment levels in shallower areas. Macronutrients 


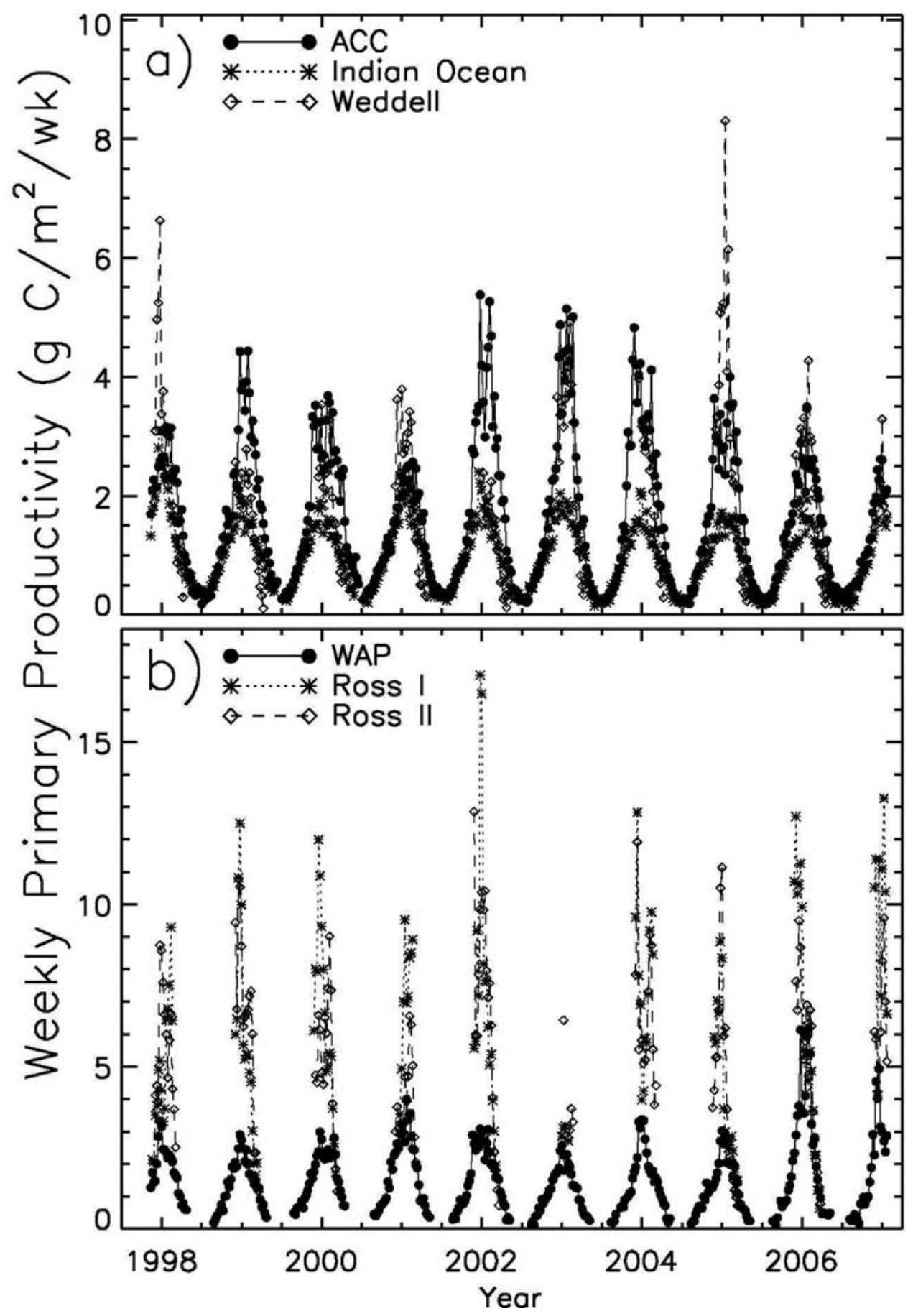

Figure 10. Primary productivity from 1997-2006 in (a) the Weddell Sea, Indian Ocean, and ACC areas and (b) the two Ross Sea regions and the West Antarctic Peninsula.

(the concentrations of inorganic nitrogen, phosphorus and silicic acid) are high throughout the Southern Ocean, and cannot explain this trend. It is possible that micronutrients, such as iron, are added to the water as it flows over sediments of the continental shelf and stimulate productivity and growth [Peloquin and Smith, 2007]. However, it is uncertain that waters in contact with the sediments are indeed enriched with micronutrients, although it has been shown that Modified Circumpolar Deep Waters are elevated in [Fe] relative to waters above [Sohrin et al., 2000; Boye et al., 2001]. Stratification is often greater on the shelf, but given the large amount of low-density, fresh water introduced by melting ice throughout the ice-covered waters at all depths of the Southern Ocean, it might be expected that blooms would occur over much greater regions of the Antarctic than they apparently do. Because shallower waters are unable to support populations of Antarctic krill [Hofmann and Murphy, 2004], it is possible that these coastal regions experience reduced grazing, but it would not explain why other grazers such as copepods or 
Table 2. Estimates of Primary Production of the Southern Ocean ${ }^{\mathrm{a}, \mathrm{b}}$

\begin{tabular}{lll}
\hline \multicolumn{1}{c}{ Area used in Estimate } & Primary Productivity, $\mathrm{g} \mathrm{C} \mathrm{m}^{-2} \mathrm{a}^{-1}$ & Reference \\
\hline $38.1 \times 10^{6} \mathrm{~km}^{2}$; south of $50^{\circ} \mathrm{S}$ & 16 & Holm-Hansen et al. $[1977]$ \\
$38.1 \times 10^{6} \mathrm{~km}^{2}$; south of $50^{\circ} \mathrm{S}$ & 43 & El-Sayed [1978] \\
Weddell Sea marginal ice zone & 30 & Jennings et al. [1983] \\
Southern Ocean marginal ice zone & 10 & Smith and Nelson [1986] \\
Weddell Sea marginal ice zone & 32.9 & Smith and Nelson [1986] \\
Ross Sea marginal ice zone & 45.6 & Smith and Nelson [1986] \\
Ross Sea continental shelf & 140 & Arrigo and McClain [1994] \\
Ross Sea continental shelf & 200 & Smith and Gordon [1997] \\
South of $50^{\circ} \mathrm{S}$ & 100 & Arrigo et al. $[1998 \mathrm{a}]$ \\
Ross Sea continental shelf & $78.7-144$ & Arrigo et al. [1998b] \\
Southern Ocean (south of $50^{\circ} \mathrm{S}$ ) & $62.4 ; 82.2^{\mathrm{a}}$ & Moore and Abbott [2000] \\
Coastal polynyas & $20-80$ & Arrigo and van Dijken [2004] \\
Southern Ocean (south of $\left.60^{\circ} \mathrm{S}\right)$ & $23.65 \pm 1.28$ & this study \\
Ross Sea I & $65.11 \pm 24.98$ & this study \\
Ross Sea II & $54.14 \pm 14.54$ & this study \\
West Antarctic Peninsula & $37.30 \pm 11.83$ & this study \\
Weddell Sea & $18.17 \pm 6.86$ & this study \\
Antarctic Circumpolar Current & $67.98 \pm 9.61$ & this study \\
Indian Ocean & $41.12 \pm 3.75$ & this study
\end{tabular}

${ }^{a}$ All estimates are not comparable, as they were derived as averages using different techniques and areas.

${ }^{b}$ Values represent the entire region and only those waters with $<70 \%$ ice cover.

Euphausia crystallarophius would not remove phytoplankton at a similar rate in the absence of Antarctic krill. Colder waters tend to decouple production and grazing, but water temperatures offshore and on the continental shelves are not substantially different (Figure 5), and so the decoupling would be expected to be similar in both. Hence the extreme productivity of the continental shelves remains an enigma; however, it may be more correct to say that the extreme lack of production in the deep water is even more of an enigma.

[26] One possible explanation for the deep water's ultraoligotrophic state might be the interactive effects of iron and irradiance. Sunda and Huntsman [1997] showed in a series of elegant experiments that at low irradiances the iron demand by phytoplankton increased. Thus, while waters off the continental shelf are indeed often stratified by meltwater inputs, mean mixed layers may be greater than those on the shelves. For example mixed layer depths in the Pacific sector (from $60^{\circ} \mathrm{S}$ to $68^{\circ} \mathrm{S}$, in waters $>2500 \mathrm{~m}$ ) during summer ranged from 5 to $89 \mathrm{~m}$ (mean $45.3 \pm 20.4 \mathrm{~m}$ ) in January-February (www.jgofs.whoi.edu). In contrast, mixed layers on the continental shelf of the Ross Sea during the same period and year averaged $24.7 \pm 14.4 \mathrm{~m}$. Thus, phytoplankton off the shelf would potentially require greater amounts of iron during growth under lower irradiance. While these waters may have slightly greater inputs of aeolian $\mathrm{Fe}$ via dust, surface layer concentrations are not dramatically different. Hence, we suggest that the lower irradiances available to phytoplankton due to greater vertical mixing induce greater iron requirements, and hence ultimately limit phytoplankton biomass and productivity in deep, oceanic waters.

[27] While the large-scale coupling between ice and primary productivity has been known for some time, few data are available over appropriate timescales to adequately define the relationship. We assessed the relationship between ice concentrations and derived monthly productivity in the four ice-covered regions for all years (the West Antarctic Peninsula, the Weddell Sea and the two sites of the southern Ross Sea; Figure 13). Little correlation between the ice and productivity was found in the WAP, either on an annual or monthly basis; however, in both of the Ross Sea sites as well as in the Weddell Sea, a strong, negative relationship was detected. This suggests that the primary, causal mechanism behind the interannual variability in the productivity of the WAP is not ice, whereas the large-scale patterns of productivity in the more southerly, ice-covered areas are largely dependent on changes in ice cover and hence irradiance availability on both annual and seasonal timescales. This furthermore suggests that if ice concentrations in the Ross Sea continue to increase, then productivity would be expected to fall as well. However, changes in ice cover on the continental shelf are far less pronounced that in other areas of the Ross Sea sector (i.e., the increases in ice cover reported by Kwok and Comiso [2002] were largely driven by changes northwest of Cape Adare, although some increases in the western Ross Sea on the continental shelf were also observed). In addition, Comiso and Nishio [2008] has detected a decrease in ice concentrations in the Pacific sector, so it remains problematic what, if any, ecosystem shifts might be occurring in water structured by ice.

[28] One of the more striking results of this work is the marked and significant increase in primary productivity of the entire Southern Ocean (Figure 9a). This change appears to be driven by changes in January and February productivity (Figures 9d and 9e) and not by changes in other months (although November, December and March also showed nonsignificant increases). The trend also is not driven by limited, regional changes; that is, we did not detect changes in the regions we selected for detailed analysis that contributed significantly to the overall trend we found in the entire Southern Ocean. The changes in productivity we found could be related to a number of environmental and oceanographic processes. For example, such changes could be induced by large-scale, increased 

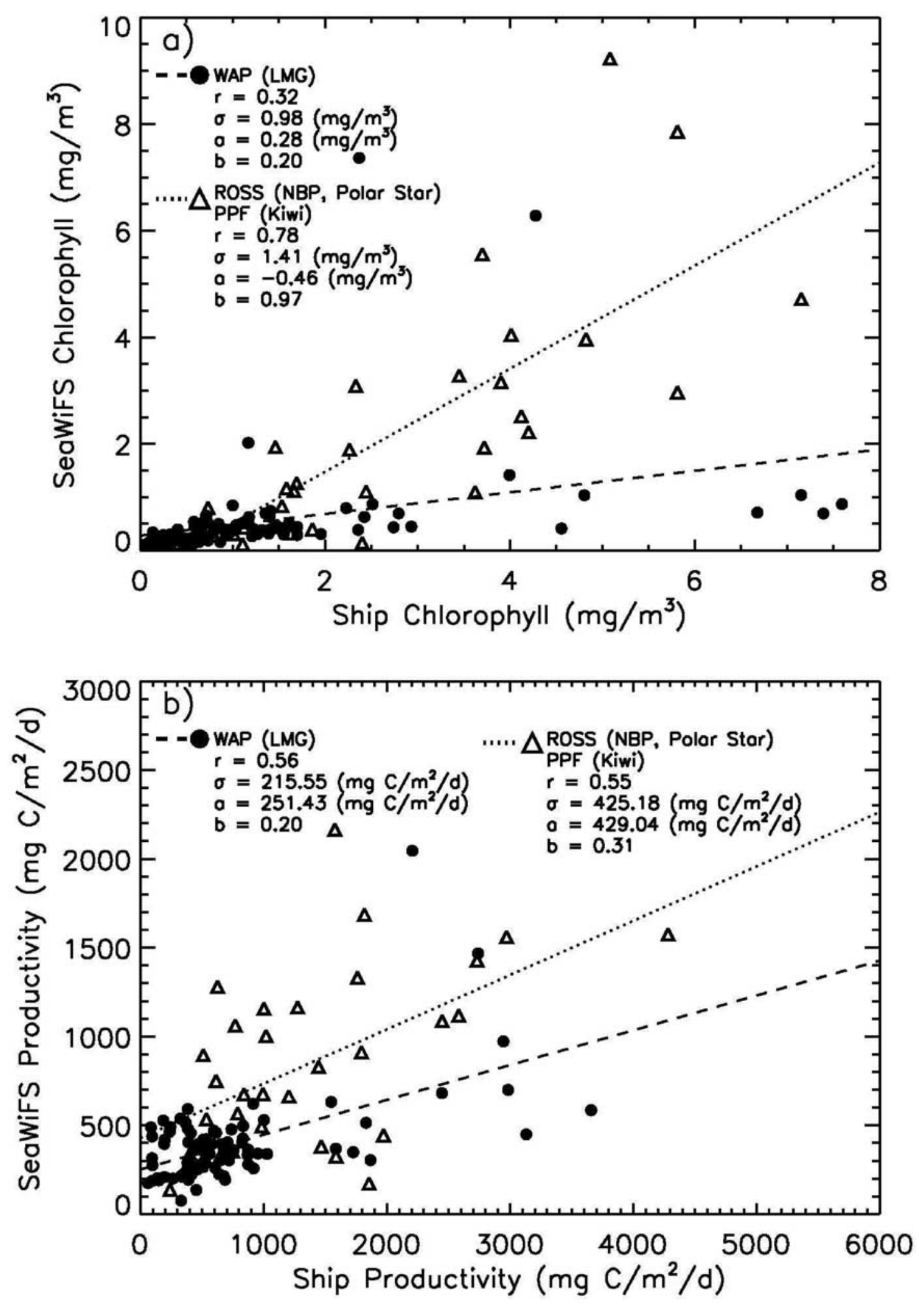

Figure 11. Relationship between (a) measured surface (mean in the upper one optical depth) chlorophyll concentration and SeaWiFS chlorophyll estimate and (b) in situ productivity and modeled productivity. Study regions include the Ross Sea continental shelf (Polar Star, NBP), WAP (LMG), and the Polar Front area of the Ross Sea sector (Kiwi). Abbreviations: r, regression coefficient; b, slope; a, y intercept; and $\sigma$, the standard deviation of the intercept. Data from W. O. Smith (unpublished, 2007), http://pal.lternet.edu/, and http://usjgofs.whoi.edu/jg/dir/jgofs/. 


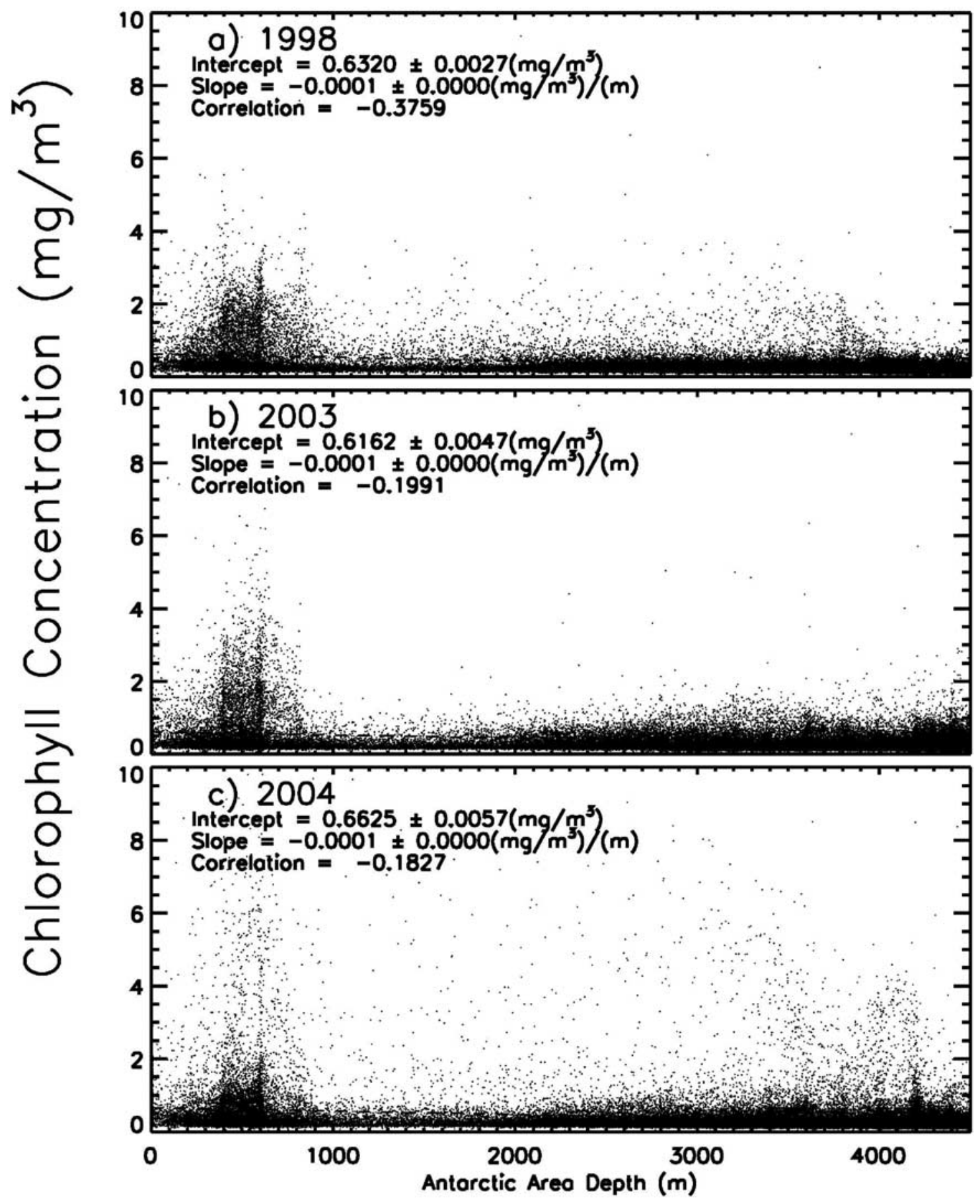

Figure 12. The relationship between depth and SeaWiFS-derived chlorophyll $a$ concentrations in the Southern Ocean during 3 years: (a) 1998, (b) 2003, and (c) 2004.

water column stratification. Such decreased mixing would result in increased irradiance availability to phytoplankton and increased growth (and potentially reduced iron demands as well). Assessing this change is impossible using the data available to us, but it is noteworthy that models have predicted that the Southern Ocean will respond to increased atmospheric changes through increased stratification induced by decreased salinity [e.g., Sarmiento and le Quéré, 1996; Sarmiento et al., 1998]. We are not suggesting that such changes are occurring as a result of increased air temperatures, but such changes might be contributing to this change. Increased productivity may also be due to enhanced iron inputs via changes in atmospheric and oceanographic circulation; again, these could not be detected from the data available to us.

[29] Behrenfeld et al. [2006], using a similar approach but on a global scale, found that since 1999 there has been a globally significant decrease in chlorophyll and productivity that was driven in large part by changes in the lower latitudes. Their analysis did include the Southern Ocean, and they found increased temperatures in the Pacific sector, but decreased temperatures in the Atlantic. They also 


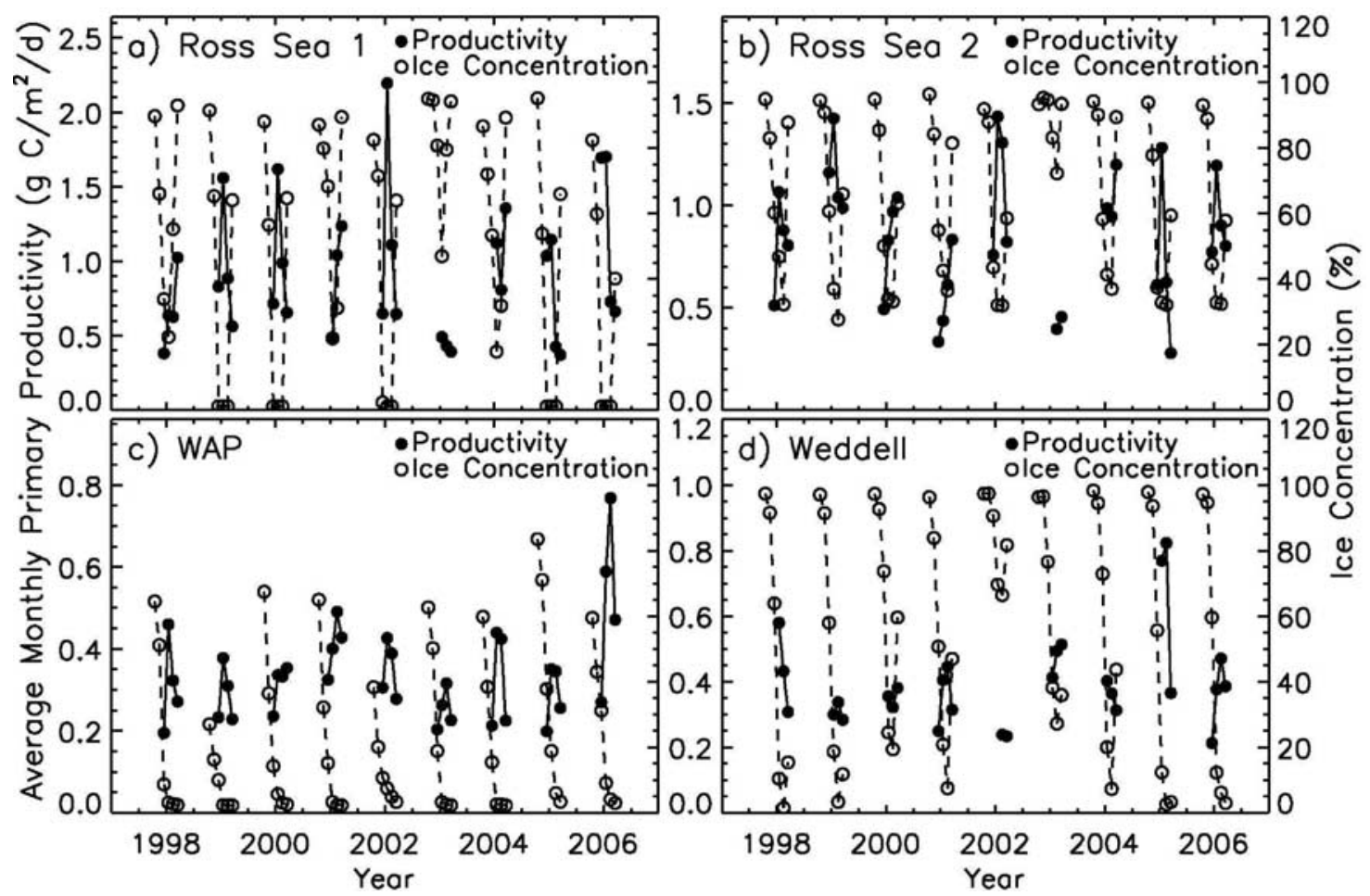

Figure 13. The relationship between ice concentration and estimated annual primary productivity from 1997-2006 in (a) Ross Sea I, (b) Ross Sea II, (c) West Antarctic Peninsula, and (d) Weddell Sea.

reported increased productivity in the deeper waters of the Pacific sector south of the Subtropical Convergence, but did not attempt to assess any changes in waters they did not consider permanently stratified (that is, south of the STC). However, their results suggest that changes have indeed occurred in the Southern Ocean, but the physical forcing for such changes remain uncertain at this time.

[30] Decadal changes in ice concentrations have been observed for some time [e.g., Kwok and Comiso, 2002], and long-term changes in ecosystem variables have also been observed [e.g., Wilson et al., 2001; Atkinson et al., 2004]. Specifically, we know that since 1979 ice extent has greatly decreased in the West Antarctic Peninsula/Bellingshausen Sea region $(\sim 7 \%$ per decade), and those in the Ross Sea have increased by $\sim 5.5 \%$ per decade [Kwok and Comiso, 2002]. It would be expected that such changes in such a major physical forcing variable would induce changes in primary productivity as well, but we were unable to discern any significant temporal trend in either the WAP or Ross Sea. The Ross Sea has exhibited very strong variability in the past decade, including a substantial change due to iceberg-driven ice concentrations. In contrast, ice does not appear to be a major control of annual productivity in the WAP, although it can impact regional food webs [Fraser and Trivelpiece, 1996]. Further analysis is needed to assess the environmental forcing of the large-scale changes we detected.

\section{Summary}

[31] The Southern Ocean shows a significant amount of interannual variability in environmental and oceanographic features, such as ice concentration, distribution, and sea surface temperatures, as well as in biological variables, such as pigment concentrations. We have shown that during the 9 years (1997-2006) analyzed in this study that ice concentrations decreased slightly ( $\sim 2 \%$ per decade). Surface layer water temperatures showed the greatest variations in areas of the Antarctic Circumpolar Current. Pigment concentrations were greatest in coastal regions; maximum values were found on the continental shelf (in 400-600 m), but not in extremely shallow waters. Few periods of enhanced pigments were observed in deep waters, and we suggest that this results from a deeper mixed layer and reduced iron concentrations, each of which by itself may not limit growth and accumulation, but the interactive effects might effectively preclude substantial phytoplankton growth.

[32] A comparison with measured and satellite-derived pigments was made, and confirmed the general agreement as well as the regional variations. A similar comparison between measured productivity and modeled productivity suggests that productivity estimates are substantially below those measured in situ. A larger, more spatially comprehensive analysis is needed to confirm these trends.

[33] Productivity in the entire Southern Ocean showed a substantial and significant increase during the 9-year observation period, and much of this increase was due to changes during the austral summer months. This suggests that accurate prediction of temporal trends in phytoplankton growth and photosynthesis does not solely depend on changes in sea ice cover alone, but that related oceanographic changes (such as in stratification, currents and iron supply) also have a significant impact. No significant changes in the productivity of our selected regions was observed, largely owing to the substantial variability of 
each region. Understanding the large-scale relationships over the entire Southern Ocean between phytoplankton growth/biomass and physical forcing are essential to a complete knowledge of the mechanisms controlling the food webs and biogeochemical cycles in the Antarctic.

[34] Acknowledgments. This research was supported by NSF grants OPP 0087401 and ANT 0338157 and NASA Cryospheric Science Program. The expert computer skills of Larry Stock of STX are gratefully acknowledged. J. Peloquin and S. Tozzi provided useful comments on an early draft. The authors acknowledge the use of data collected by M. Verne as part of the Palmer LTER program in generating Figure 11. This is VIMS contribution 2924

\section{References}

Alexander, V., and H. J. Niebauer (1981), Oceanography of the eastern Bering Sea ice-edge zone in spring, Limnol. Oceanogr., 26, 1111-1125. Arrigo, K. R., and C. R. McClain (1994), Spring phytoplankton production in the western Ross Sea, Science, 266, 261-263, doi:10.1126/ science. 266.5183 .261

Arrigo, K. R., and G. L. van Dijken (2004), Annual cycles of sea ice and phytoplankton in the Cape Bathurst polynya, southeastern Beaufort Sea, Canadian Arctic, Geophys. Res. Lett., 31, L08304, doi:10.1029/ 2003GL018978.

Arrigo, K. R., D. L. Worthen, M. P. Lizzote, P. Dixon, and G. Dieckmann (1997), Primary production in Antarctic sea ice, Science, 276, 394-397, doi:10.1126/science.276.5311.394.

Arrigo, K. R., A. M. Weiss, and W. O. Smith Jr. (1998a), Physical forcing of phytoplankton dynamics in the western Ross Sea, J. Geophys. Res., 103, 1007-1022, doi:10.1029/97JC02326.

Arrigo, K. R., D. L. Worthen, A. Schnell, and M. P. Lizzote (1998b), Primary production in Southern Ocean waters, J. Geophys. Res., 103, 15,587-15,600, doi:10.1029/98JC00930.

Atkinson, A., V. Siegel, E. Pakhomov, and P. Rothery (2004), Long-term decline in krill stock and increase in salps within the Southern Ocean, Nature, 432, 100-103, doi:10.1038/nature02996.

Behrenfeld, M. J., and P. G. Falkowski (1997), A consumer's guide to phytoplankton primary productivity models, Limnol. Oceanogr., 42, $1-20$.

Behrenfeld, M., E. Maranon, D. A. Siegel, and S. B. Hooker (2002), Photoacclimation and nutrient-based model of light-saturated photosynthesis for quantifying ocean primary production, Mar. Ecol. Prog. Ser, 228, 103-117, doi:10.3354/meps228103.

Behrenfeld, M. J., R. T. O'Malley, D. A. Siegel, C. R. McClain, J. L. Sarmiento, G. C. Feldman, A. J. Milligan, P. G. Falkowski, R. C. Letelier, and E. S. Boss (2006), Climate-driven trends in contemporary ocean productivity, Nature, 444, 752-755, doi:10.1038/nature 05317.

Bouman, H., T. Platt, S. Sathyendranath, and V. Stuart (2005), Dependence of light-saturated photo-synthesis on temperature and community structure, Deep Sea Res., Part I, 52, 1284-1299, doi:10.1016/j.dsr.2005.01.008.

Boyd, P. W., C. Robinson, G. Savidge, and P. J. L. B. Williams (1995), Water column and sea-ice primary production during Austral spring in the Bellingshausen Sea, Deep Sea Res., Part II, 42, 1177-1200, doi:10.1016/0967-0645(95)00070-7.

Boyd, P. W., et al. (2000), A mesoscale phytoplankton bloom in the polar Southern Ocean stimulated by iron fertilization, Nature, 407, 695-702, doi: $10.1038 / 35037500$.

Boye, M., C. M. G. van den Berg, J. T. M. de Jong, J. Leach, P. Croot, and H. J. W. de Baar (2001), Organic complexation of iron in the Southern Ocean, Deep Sea Res., Part I, 48, 1477-1497, doi:10.1016/S09670637(00)00099-6.

Campbell, J., et al. (2002), Comparison of algorithms for estimating ocean primary production from surface chlorophyll, temperature, and irradiance, Global Biogeochem. Cycles, 16(3), 1035, doi:10.1029/2001GB001444.

Comiso, J. C. (2003), Warming trends in the Arctic from clear sky satellite observations, J. Clim., 16, 3498-3510, doi:10.1175/15200442(2003)016<3498:WTITAF $>2.0$. CO;2.

Comiso, J. C. (2004), Sea ice algorithm for AMSR-E, Riv. Ital. Telerilev., $30 / 31,119-130$.

Comiso, J. C., and F. Nishio (2008), Trends in the sea ice cover using enhanced and compatible AMSR-E, SSM/I, and SMMR data, J. Geophys. Res., 113, C02S07, doi:10.1029/2007JC004257.

Comiso, J. C., C. McClain, C. Sullivan, J. Ryan, and C. L. Leonard (1993), CZCS pigment concentrations in the Southern Ocean and their relationships to some geophysical parameters, J. Geophys. Res., 98, 2419-2451, doi:10.1029/92JC02505.
Comiso, J. C., D. J. Cavalieri, and T. Markus (2003), Sea ice concentration, ice temperature, and snow depth, using AMSR-E data, IEEE Trans. Geosci. Remote Sens., 41, 243-252.

Dierssen, H. M., and R. C. Smith (2000), Biol.-optical properties and remote sensing ocean color algorithms for Antarctic Peninsula waters, J. Geophys. Res., 105, 26,301-26,312, doi:10.1029/1999JC000296.

El-Sayed, S. Z. (1978), Primary productivity and estimates of potential yield of the Southern Ocean, in Polar Research: To the Present and to the Future, edited by M. A. McWhinnie, pp. 141-160, Westview, Boulder, Colo.

Fraser, W. R., and W. Z. Trivelpiece (1996), Factors controlling the distribution of seabirds: winter-summer heterogeneity in the distribution of Adélie penguin populations, in Foundations for Ecological Research West of the Antarctic Peninsula, Antarct. Res. Ser, vol. 70, edited by R. M. Ross, E. E. Hofmann, and L. B. Quetin, pp. 257-272, AGU, Washington, D. C.

Garcia, C. A. E., V. M. T. Garcia, and C. R. McClain (2005), Evaluation of SeaWiFS chlorophyll algorithms in the Southwestern Atlantic and Southern Oceans, Remote Sens. Environ., 95, 125-137, doi:10.1016/ j.rse.2004.12.006.

Gregg, W. W., and K. L. Carder (1990), A simple spectral solar irradiance model for cloudless maritime atmospheres, Limnol. Oceanogr., 35, $1657-1675$.

Gregg, W. W., and N. W. Casey (2004), Global and regional evaluation of the SeaWiFS chlorophyll data set, Remote Sens. Environ., 93, 463-479, doi:10.1016/j.rse.2003.12.012.

Hall, A., and M. Visbeck (2002), Synchronous variability in the Southern Hemisphere atmosphere, sea ice, and ocean resulting from the annular mode, J. Clim., 15, 3043-3057, doi:10.1175/15200442(2002)015<3043: SVITSH $>2.0$. CO;2.

Hiscock, M. R., J. Marra, W. O. Smith Jr., R. Goericke, C. Measures, S. Vinke, R. Olson, H. Sosik, and R. T. Barber (2003), Primary productivity and its regulation in the Pacific Sector of the Southern Ocean, Deep Sea Res., Part II, 50, 533-558, doi:10.1016/S0967-0645(02)00583-0.

Hofmann, E. E., and E. J. Murphy (2004), Advection, krill, and Antarctic marine ecosystems, Antarct. Sci., 16, 487-500.

Holm-Hansen, O., S. Z. El-Sayed, G. A. Francescini, and R. L. Cuhel (1977), Primary production and factors controlling phytoplankton growth in the Southern Ocean, in Adaptations Within Antarctic Ecosystems, edited by G. A. Llano, pp. 11-50, Gulf, Houston, Tex.

Holm-Hansen, O., et al. (2004), Temporal and spatial distribution of chlorophyll-a in surface waters of the Scotia Sea as determined by both shipboard measurements and satellite data, Deep Sea Res., Part II, 51, $1323-1331$

Korb, R. E., M. J. Whitehouse, and P. Ward (2004), SeaWiFS in the Southern Ocean: Spatial and temporal variability in phytoplankton biomass around South Georgia, Deep Sea Res., Part II, 51, 99-116, doi:10.1016 j.dsr2.2003.04.002.

Kwok, R., and J. C. Comiso (2002), Spatial patterns of variability in Antarctic surface temperature: Connections to the Southern Hemisphere Annular Mode and the Southern Oscillation, Geophys. Res. Lett. 29(14), 1705, doi:10.1029/2002GL015415.

Lance, V. P., M. H. Hiscock, A. K. Hilting, D. K. Stuebe, R. R. Bidigare, W. O. Smith Jr., and R. T. Barber (2007), Primary productivity, differential size fractionation and pigment composition responses in two Southern Ocean in situ iron enrichment experiments, Deep Sea Res., Part I, 54, 747-773, doi:10.1016/j.dsr.2007.02.008.

Lazzara, L., I. Nardello, C. Ermanni, O. Mangoni, and V. Sagiomo (2007), Light environment and seasonal dynamics in microalgae in the annual sea ice at Terra Nova Bay, Ross Sea, Antarctica, Antarct. Sci., 19, 83-92.

Marrari, M., C. M. Hu, and K. Daly (2006), Validation of SeaWiFS chlorophyll $a$ concentrations in the Southern Ocean: A revisit, Remote Sens. Environ., 105, 367-375, doi:10.1016/j.rse.2006.07.008.

Mitchell, B. G., and O. Holm-Hansen (1991), Observations and modeling of the Antarctic phytoplankton crop in relation to mixing depth, Deep Sea Res., 38, 981-1008, doi:10.1016/0198-0149(91)90093-U.

Moffat, C., R. Beardsley, B. Owens, and N. van Leipzig (2008), A first description of the Antarctic Peninsula coastal current, Deep Sea Res., Part II, in press.

Moore, J. K., and M. R. Abbott (2000), Phytoplankton chlorophyll distributions and primary production in the Southern Ocean, J. Geophys. Res., 105, 28,709-28,722, doi:10.1029/1999JC000043.

Moore, J. K., and M. R. Abbott (2002), Surface chlorophyll concentrations in relation to the Antarctic Polar Front: Seasonal and spatial patterns from satellite observations, J. Mar. Syst., 37, 69-86, doi:10.1016/S09247963(02)00196-3.

Moore, J. K., M. R. Abbott, J. G. Richman, W. O. Smith Jr., T. J. Cowles, K. H. Coale, W. D. Gardner, and R. T. Barber (1999), SeaWiFS satellite 
ocean color data at the U.S. Southern Ocean JGOFS line along $170^{\circ} \mathrm{W}$, Geophys. Res. Lett., 26, 1465-1468, doi:10.1029/1999GL900242.

Nelson, D. M., W. O. Smith Jr., L. I. Gordon, and B. Huber (1987), Early spring distributions of nutrients and phytoplankton biomass in the iceedge zone of the Weddell/Scotia Sea, J. Geophys. Res., 92, 7181-7190, doi:10.1029/JC092iC07p07181.

Patt, F. S., et al. (2003), Algorithm updates for the Fourth SeaWiFS data reprocessing, NASA/TM-2003-206892, 74 pp., NASA Goddard Space Flight Cent., Greenbelt, Md.

Peloquin, J. A., and W. O. Smith Jr. (2007), Phytoplankton blooms in the Ross Sea, Antarctica: Interannual variability in magnitude, temporal patterns, and composition, J. Geophys. Res., 112, C08013, doi:10.1029/ 2006JC003816.

Robinson, D. H., K. R. Arrigo, G. R. DiTullio, and M. P. Lizzotte (2003), Evaluating photosynthetic carbon fixation during Phaeocystis antarctica blooms, in Biogeochemistry of the Ross Sea, Antarct. Res. Ser., vol. 78, edited by G. R. DiTullio and R. B. Dunbar, pp. 179-196, AGU, Washington, D. C.

Sarmiento, J. L., and C. le Quéré (1996), Oceanic carbon dioxide uptake in a model of century-scale global warming, Science, 274, 1346-1350, doi:10.1126/science.274.5291.1346.

Sarmiento, J. L., T. M. C. Hughes, R. J. Stouffer, and S. Manabe (1998), 1998 , Simulated response of the ocean carbon cycle to anthropogenic climate warming, Nature, 393, 245-249, doi:10.1038/30455.

Smith, W. O., Jr. (1995), Primary productivity and new production in the Northeast Water polynya during summer, 1992, J. Geophys. Res., 100 4357-4370, doi:10.1029/94JC02764.

Smith, W. O., Jr., and V. A. Asper (2001), The influence of phytoplankton assemblage composition on biogeochemical characteristics and cycles in the southern Ross Sea, Antarctica, Deep Sea Res., Part I, 48, 137-161, doi:10.1016/S0967-0637(00)00045-5.

Smith, W. O., Jr., and L. I. Gordon (1997), Hyperproductivity of the Ross Sea (Antarctica) polynya during austral spring, Geophys. Res. Lett., 24, 233-236, doi:10.1029/96GL03926.

Smith, W. O., Jr., and D. M. Nelson (1985), Phytoplankton bloom produced by a receding ice edge in the Ross Sea: Spatial coherence with the density field, Science, 227, 163-166, doi:10.1126/science.227.4683.163.

Smith, W. O., Jr., and D. M. Nelson (1986), The importance of ice-edge blooms in the Southern Ocean, Bioscience, 36, 251-257, doi:10.2307/ 1310215.

Smith, W. O., Jr., A. R. Shields, J. A. Peloquin, G. Catalano, S. Tozzi, M. S. Dinniman, and V. A. Asper (2006), Biogeochemical budgets in the Ross Sea: Variations among years, Deep Sea Res., Part II, 53, 815-833, doi:10.1016/j.dsr2.2006.02.014.

Sohrin, Y., S. Iwarnoto, M. Matsui, H. Obata, E. Nakayama, K. Suzuki, N. Handa, and M. Ishii (2000), The distribution of Fe in the Australian sector of the Southern Ocean, Deep Sea Res., Part I, 47, 55-84, doi:10.1016/S0967-0637(99)00049-7.

Strutton, P. G., F. B. Griffiths, R. L. Waters, S. W. Wright, and N. L. Bindoff (2000), Primary productivity of the coast of East Antarctica $\left(80-150^{\circ} \mathrm{E}\right)$ : January to March, 1996, Deep Sea Res., Part II, 47, 2327-2362, doi:10.1016/S0967-0645(00)00028-X.

Sullivan, C. W., K. R. Arrigo, C. R. McClain, J. C. Comiso, and J. Firestone (1993), Distributions of phytoplankton blooms in the Southern Ocean, Science, 262, 1832-1837, doi:10.1126/science.262.5141.1832.

Sunda, W. G., and S. A. Huntsman (1997), Interrelated influence of iron, light and cell size on marine phytoplankton growth, Nature, 390, 389-392, doi:10.1038/37093.

Thomas, D. N. (2004), Frozen Oceans: The Floating World of Pack Ice, 224 pp., Firefly, Richmond Hill, Ont., Canada.

Tremblay, J.-E., and W. O. Smith Jr. (2007), Phytoplankton processes in polynyas, in Polynyas: Windows to the World's Oceans, edited by W. O. Smith Jr. and D. G. Barber, pp. 239-270, Elsevier, Amsterdam.

van Hilst, C. M., and W. O. Smith Jr. (2002), Photosynthesis/irradiance relationships in the Ross Sea, Antarctica and their control by phytoplankton assemblage composition and environmental factors, Mar. Ecol. Prog. Ser, 226, 1-12.

Waldron, H. N., C. G. Attwood, T. A. Probyn, and M. I. Lucas (1995), Nitrogen dynamics in the Bellingshausen Sea during the austral spring of 1992, Deep Sea Res., Part II, 42, 1253-1276, doi:10.1016/09670645(95)00063-V

Wilson, P. R., D. G. Ainley, N. Nur, S. S. Jacobs, K. J. Barton, G. Ballard, and J. Comiso (2001), Adélie penguin population change in the Pacific sector of Antarctica: Relation to sea-ice extent and the Antarctic Circumpolar Current, Mar. Ecol. Prog. Ser., 213, 301-309, doi:10.3354/ meps 213301 .

Zwally, H. J., J. C. Comiso, C. Parkinson, D. Cavalieri, and P. Gloersen (2002), Variability of the Antarctic sea ice cover, J. Geophys. Res., 107(C5), 3041, doi:10.1029/2000JC000733.

J. C. Comiso, NASA Goddard Space Flight Center, Code 614.1, Greenbelt, MD 20771, USA.

W. O. Smith Jr., Virginia Institute of Marine Sciences, College of William and Mary, Gloucester Pt., VA 23062, USA. (wos@vims.edu) 